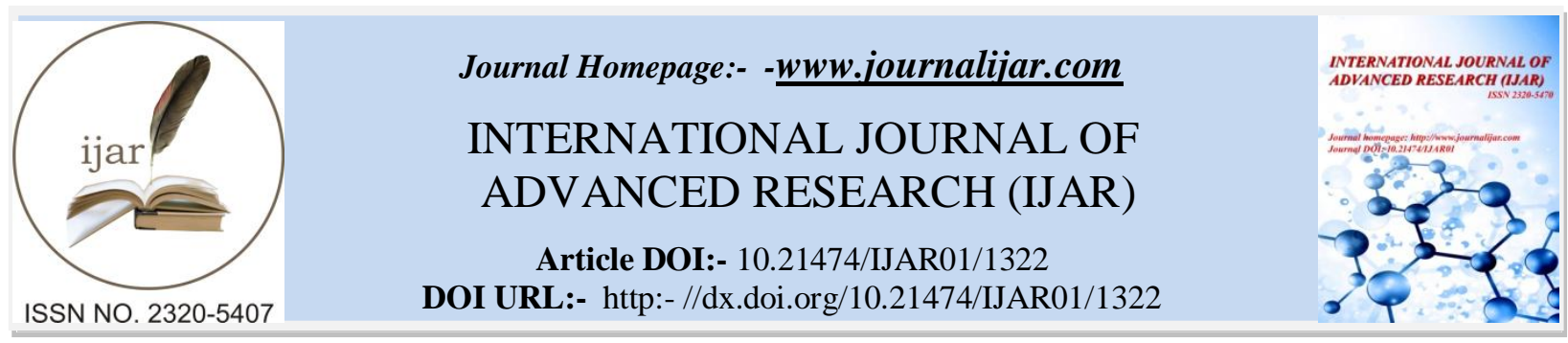

RESEARCH ARTICLE

\title{
CONTRIBUTION TO THE KNOWLEDGE OF THE LESSER ANTILLES FLORA:- STUDY OF THE CASE-NAVIRE, NATURALISTIC AREA OF ECOLOGICAL FAUNA AND FLORA INTEREST (MARTINIQUE).
}

\section{"Philippe JOSEPH ${ }^{1,2}$, Jean-Emile SIMPHOR ${ }^{1}$, Kevine BAILLARD ${ }^{1,2}$, Jean-Philippe CLAUDE $^{1,2}$, Yelji ABATI ${ }^{1,2}$, Yanis JEAN-FRANCOIS ${ }^{1,2}$ and Séverine ELY-MARIUS ${ }^{1,2}$.}

1. Bioreca.

2. Umr space dev.

\section{Manuscript Info} (.......................... Manuscript History

Received:- 12 June 2016 Final Accepted:- 19 July 2016

Published:- August 2016

Key words:- -

Lesser Antilles, Martinique, Vegetation, Anthropization, succession.

\section{Abstract}

The complexity of the Lesser Antilles vegetation must be linked to the variety of topographic features that influence the structure of some climatic parameters, particularly the rainfall. The above mentioned environmental factors influence a plurality of biotopes colonized by specific phytocenoses. Using survey transects of different minimal areas, we highlighted the specific, biocenotic, structural and architectural heterogeneity of the survey stations. This spatio-temporal differentiation of plant groupings is strongly guided by the activities of the successive human societies. These elements show that the anthropized vegetation of the Lesser Antilles represents a true laboratory for the study of plant succession using the synchronic approach.

Copy Right, IJAR, 2016,. All rights reserved.

\section{Introduction:- -}

True islands are essential systems for the study of migrations, in particular plant migration and the factorial determinism that cause the spatial and temporal species dynamics and the multiple combinations they form (Leigh et al. 1993; Denslowet al., 2009; Mueller-Dombois and Fosberg, 2013; Knight, 1975, Ruiz et al., 2005; SantiagoValentin \& Olmstead, 2004). In fact, the distance between the islands and the continents, their size, their geomorphology and the effectiveness of their diaspore dispersion are other elements affecting their biodiversity irrespective of the level of specific complexity (Rizali et al., 2010; Caujape-Castells et al., 2010; Brown, 1978; Whittaker et al. 2010; Morrison, 2010). Due to their smallness and lack of biosystem redundancy, the islands are vulnerable to human activities (Cole et al., 2010; Fordham and Brook, 2010; Jenkins et al., 2010; Samways et al., 2010). This is even more important when the human footprint on the territories is significant (Bayliss-Smith et al., 2003). The erosion of biological diversity subsequent to biotope loss or modification and the population potentialization of the introduced species are among the main consequences (Rasingam and Parthasarathy, 2009; O'Dowdet al. 2003; Meyer and Lavergne, 2004; Powellet al.,2011; Mueller-Dombois and Fosberg, 2013). Within the main oceans many islands are losing their ecosystem resilience and are constantly forced to face invasive species as well as the overwhelming effects of atmospheric dynamics (Cyclones, hurricanes, typhoons; Keitt et al., 2011; Stohlgren et al., 1999; Reilly, 1991; Burslemet al., 2000; Imbertet al. 1996; Schnitzler et al. 2012). Faced with this reality, many island territories have launched programs for the protection of their biodiversity with the aim of maintaining a large number of biological organisations (Myers et al.,2000; Mittermeier et al., 1998; Loope and 
Giambelluca, 1998). This occurs because the plant community components represent resources and also participate in the biological cycles ensuring the planet's homeostasis at all levels of integration (Rispoli, 2014). The Lesser Antilles are no exception from this global phenomenon of deregulation due to human impacts (Joseph, 2012; Cano et al., 2009; Losos and Ricklefs, 2009; Helmer et al., 2008) because they have always faced and are still facing heavy human stress. Rich in a plurality of life forms subject to anthropic erosion, this archipelago is part of 24 world biodiversity Hotspots:- the Caribbean one (Myers et al., 2000; Cincottaet al., 2000;Figure 1). In the light of the regular loss of biotopes and therefore of plant taxa and in order to create protected terrestrial areas, it was essential to implement a program of inventories of the Natural Areas of Ecological, Fauna and Flora Interest (ZNIEFF) in Martinique. In this article we will discuss the main ecological and floristic features of a ZNIEFF located in the South of the Caribbean side of the island of Martinique (Figure 1).

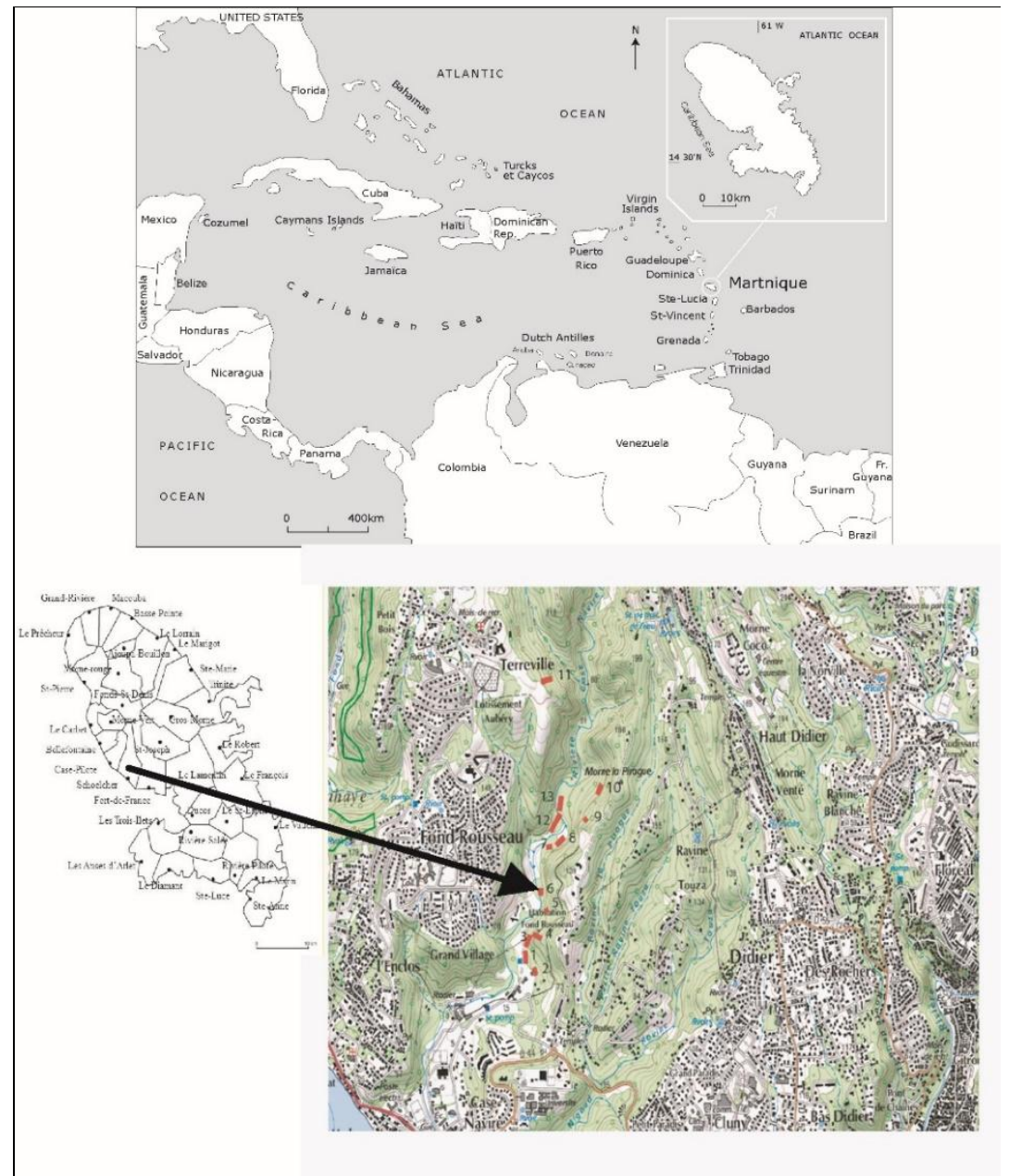

Figure 1:- - Martinique in the Caribbean - Geo-referenced survey stations in the Natural Zone of Ecological Floristics and Fauna interest of Case Navire

\section{Materials:- -}

The study area is located in the commune of Schoelcher, on the Northern Caribbean coast of Martinique to the West of Fort-de-France (Figure 1). Due to a topographic and pluviometric gradient (between $1500 \mathrm{~mm}$ and $3000 \mathrm{~mm}$ ) as well as to the Case-Navire river, this site offers a large enough variety of environments creating multiple floristic and soil potentials (Joseph, 2012). The numerous topographical facets represent as many biotopes which allowed and still allow the establishment of very specific plural floristic communities. There are evergreen seasonal tropical plant formations (mesophilic) on the protected slopes and riparian terraces affected by the sub-humid wet bioclimate, evergreen seasonal tropical plant formations of the lower horizons and with xeric features (xerophilic) on exposed slopes and ridges under the influence of the sub-humid dry bioclimate and tropical seasonal ombroevergreen plant formations (hygro-mesophilic) on the riparian terraces and the protected slopes in the interior of the 
land characterized by the sub-humid and wet bioclimates (Joseph, 2013). The vast majority of this vegetation is anthropized but in a manner diversified from the point of view of frequency and intensity. Together they form a floristic mosaic where the components have different ages, physical and floristic compositions. We can observe generalist species of the pioneer or post-pioneer stages in combination with others belonging to the advanced stages of plant succession. However, the very varied geomorphology of this part of the municipality of Schoelcher did not allow us to explore the very specific biotopes which lie within the rock ledges where the vegetation is mostly lithophile (Figures 2 a \& b). In fact, this area was deeply modified (changed) by human activities that have increased strongly since 1635 , the date when the French took possession of the island. The number and types of selected stations allowed us to acquire a fairly accurate picture of the floristic and ecosystem complexity of the study area (Figure 1).

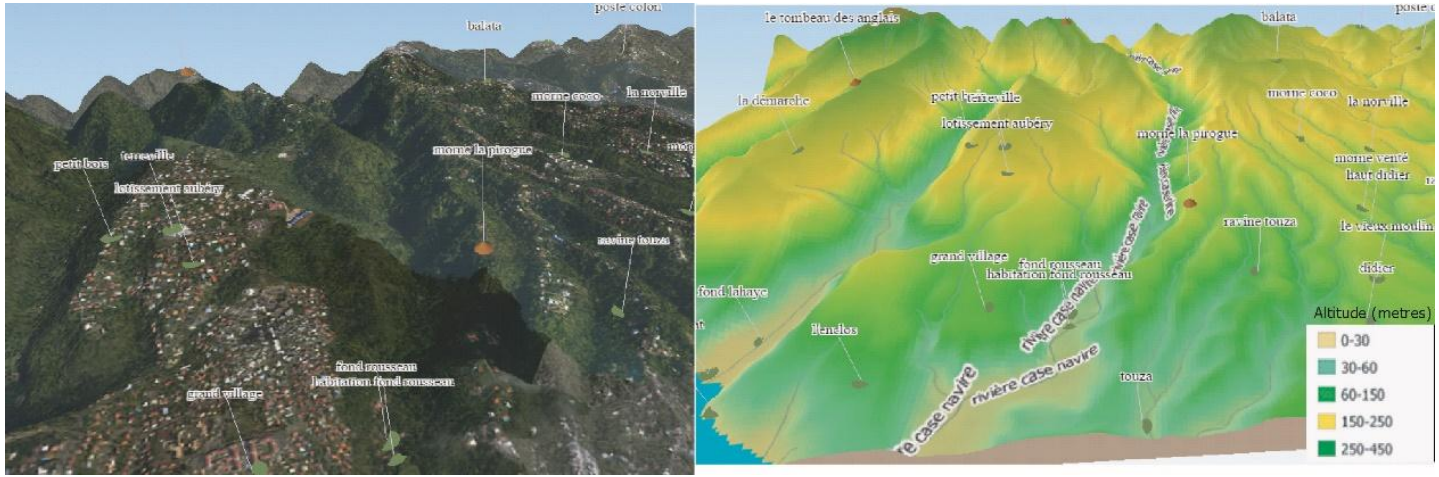

Figures 2 a \& b:- - Modelling of the Fond Rousseau ZNIEFF from aerial photographs.

\section{Methods:- -}

We conducted surveys which show the diversity of plant species and the associations they form. We have listed 13 stations on the basis of their topographic characteristics. The purpose was to compare the latest changes and understand the spatial distribution of the main species. The method used for this study is part of the macro-ecology. The objective was to decipher the structural, architectural and functional vegetation dimensions. We used transects subdivided in quadrats, depending on the minimal survey area (between 400 to $\left.1000 \mathrm{~m}^{2}\right)^{1}$ we have generated data that are both ecological and floristic descriptors (Figure 3):- species, number of individuals in populations of regeneration plant species to mature specimens (bio-demographic aspect), diametric classes (sections measured at $1.33 \mathrm{~m}$ from the ground in accordance with the international standards), total height and the first branching classes.

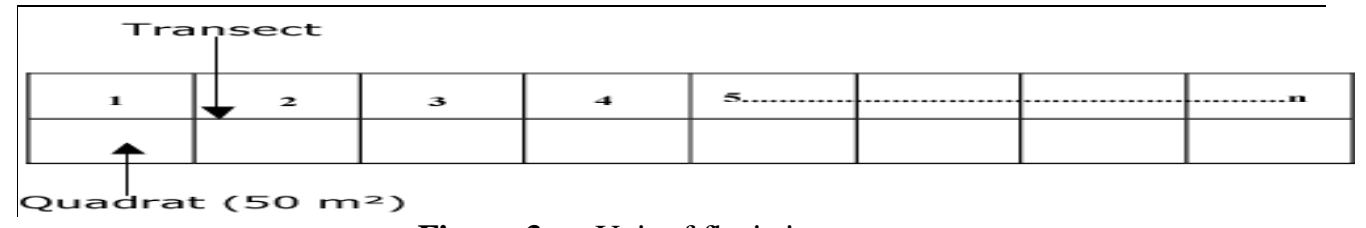

Figure 3:- - Unit of floristic surveys

\section{These elements have enabled us:- -}

-to assess the distribution of the tree sections, the formations' architecture, the characteristics of the canopies, -to evaluate the phytomass or biovolumes using the basal area that corresponds to the sum of the circle areas consisting in sections measured at $1.33 \mathrm{~m}$ from the ground.

-to know the species distribution between the transect quadrats and stations using the Distribution Index that corresponds to the following formula:- $\mathrm{Id}=\mathrm{fr} \times \mathrm{d}$ (fr being the relative frequency and $\mathrm{d}(\mathrm{nb} / \mathrm{sr}$ ) the density corresponding to the number of individuals of the species (nb) divided by the survey area (sr).

-to know the relative dominance of plant species in relation with each other through the Dominance index (ID). ID = Id $\times$ St (basal area).

\footnotetext{
${ }^{1}$ The minimal surface (or basal area) corresponds to the smallest surface unit of a floristic station considered homogeneous from the point of view of mesological factors or environmental factors in principal the climate.
} 
Aside from the dominance index (ID), the comparison between stations and the affine floristic groups of the latter was carried out due to:- -.

-a factorial analysis of correspondences (AFC) using the XLSTAT software (new version).

-the use of a datamining descriptive classification technique:- the clustering. It regroups the species in a limited number of groups or clusters. These clusters are not predefined by the analyst but discovered after the implementation of the algorithms. These clusters include species with similar ecological characteristics and species with different environmental characteristics (internal homogeneity and external heterogeneity). Unlike the factorial analysis component (AFC), this method has the big advantage of taking into account all variables without a lower dimensional subspace projection. No information is lost as a result. The results below were obtained using the SimpleKmeans and EM (Expectation, maximization) algorithms which are two algorithms commonly used for the implementation of clustering techniques.

\section{Results:- -}

General descriptions of the stations:- -

Station 1:- -Evergreen seasonal tropical forest formation $\left(765 \mathrm{~m}^{2}\right.$, Riparian terrace, Figure 1).

This phytocenosis also called mesophilic exhibits average anthropization and ranks at barely structured secondary stage (two defined strata). The most competing species appear to be in order of ecological importance (Table 1):Funtumia elastica (naturalized and potentially invasive species),Piper amalago and Samanea saman. Funtumia elastica and Piper amalago have significant density and a high relative frequency while the small number of Samanea saman is offset by the total basal areas or the high total basal areas. Apart from Pisonia fragrans and Eugenia monticola which have a distribution index close to that of the previous species, the others cumulate and exhibit low density and a much lower total basal area. Figures 4 and 5 show a section and height distribution typical of plant communities which are continuously rejuvenated due to human activities or natural hazards. The majority of surveyed individuals have diameters ranging between 2.5 and 5 centimetres. They (the individuals) reach heights ranging between 1 and $8 \mathrm{~m}$. These populations characterized by small sections and small sizes form a floristic matrix surpassed by a discontinuous stratum (an open stratum) of Samanea saman. In reality station 1 is composed of individuals of species at different stages of their development (phenology) associated with mature trees, such as the Samanea Saman, with important biovolumes. Within these regenerations, unlike the Funtumnia elastica which is highly distributed, we see the Cupania americana which is a rare and very little represented species (Figure 4).

Table 1:- - The main ecological and structural parameters of the dominant species

\begin{tabular}{|c|c|c|c|c|c|c|c|c|}
\hline Species & Families & $\begin{array}{l}\text { Absolute } \\
\text { frequenc } \\
\mathrm{y}\end{array}$ & $\begin{array}{l}\text { Relative } \\
\text { frequenc } \\
\mathrm{y}\end{array}$ & $\begin{array}{l}\text { Number } \\
\text { of } \\
\text { individual } \\
\mathrm{s}(*)\end{array}$ & Density & $\begin{array}{l}\text { Distribution } \\
\text { index }\end{array}$ & $\begin{array}{lr}\text { Total basal } \\
\text { area by } \\
\text { species }\end{array}$ & $\begin{array}{l}\text { Dominance } \\
\text { index }\end{array}$ \\
\hline $\begin{array}{l}\text { Piper } \\
\text { amalago }\end{array}$ & Piperaceae & 9 & $100 \%$ & 77 & $\begin{array}{l}0,10065359 \\
5\end{array}$ & $\begin{array}{l}0,10065359 \\
5\end{array}$ & 0,07163125 & $\begin{array}{l}0,00720994 \\
3\end{array}$ \\
\hline $\begin{array}{l}\text { Funtumi } \\
\text { a elastica }\end{array}$ & Apocynaceae & 8 & $89 \%$ & 51 & $\begin{array}{l}0,06666666 \\
7\end{array}$ & $\begin{array}{l}0,05925925 \\
9\end{array}$ & $\begin{array}{l}0,10155937 \\
5\end{array}$ & $\begin{array}{l}0,00601833 \\
3\end{array}$ \\
\hline $\begin{array}{l}\text { Samanea } \\
\text { saman }\end{array}$ & Mimosaceae & 5 & $56 \%$ & 5 & $\begin{array}{l}0,00653594 \\
8\end{array}$ & $\begin{array}{l}0,00363108 \\
2\end{array}$ & 1,6328 & $\begin{array}{l}0,00592883 \\
1\end{array}$ \\
\hline $\begin{array}{l}\text { Inga } \\
\text { ingoides }\end{array}$ & Mimosaceae & 9 & $100 \%$ & 29 & $\begin{array}{l}0,03790849 \\
7\end{array}$ & $\begin{array}{l}0,03790849 \\
7\end{array}$ & $\begin{array}{l}0,11725937 \\
5\end{array}$ & $\begin{array}{l}0,00444512 \\
7\end{array}$ \\
\hline $\begin{array}{l}\text { Cordia } \\
\text { sulcata }\end{array}$ & $\begin{array}{l}\text { Boraginacea } \\
\mathrm{e}\end{array}$ & 7 & $78 \%$ & 27 & $\begin{array}{l}0,03529411 \\
8\end{array}$ & 0,02745098 & $\begin{array}{l}0,14473437 \\
5\end{array}$ & 0,0039731 \\
\hline $\begin{array}{l}\text { Pisonia } \\
\text { fragrans }\end{array}$ & $\begin{array}{l}\text { Nyctaginace } \\
\text { ae }\end{array}$ & 9 & $100 \%$ & 59 & $\begin{array}{l}0,07712418 \\
3\end{array}$ & $\begin{array}{l}0,07712418 \\
3\end{array}$ & $\begin{array}{l}0,02894687 \\
5\end{array}$ & $\begin{array}{l}0,00223250 \\
4\end{array}$ \\
\hline $\begin{array}{l}\text { Eugenia } \\
\text { monticol } \\
\text { a }\end{array}$ & Myrtaceae & 9 & $100 \%$ & 40 & $\begin{array}{l}0,05228758 \\
2\end{array}$ & $\begin{array}{l}0,05228758 \\
2\end{array}$ & 0,019625 & $\begin{array}{l}0,00102614 \\
4\end{array}$ \\
\hline
\end{tabular}

Absolute frequency:- presence of the species in different quadrats. / Relative frequency $=$ absolute frequency / per number of quadrats $/$ Density $=$ number of individuals / station surface / Distribution index $=$ Relative frequency $x$ Density $/$ Dominance index $=$ Distribution index $\times$ Basal surface (basal area). $(*):-$ Species apart from the regenerations 


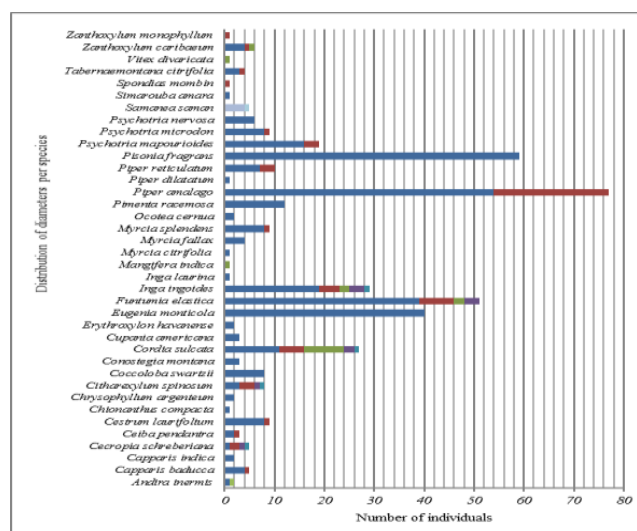

Figure 4:- - Distribution of diameters

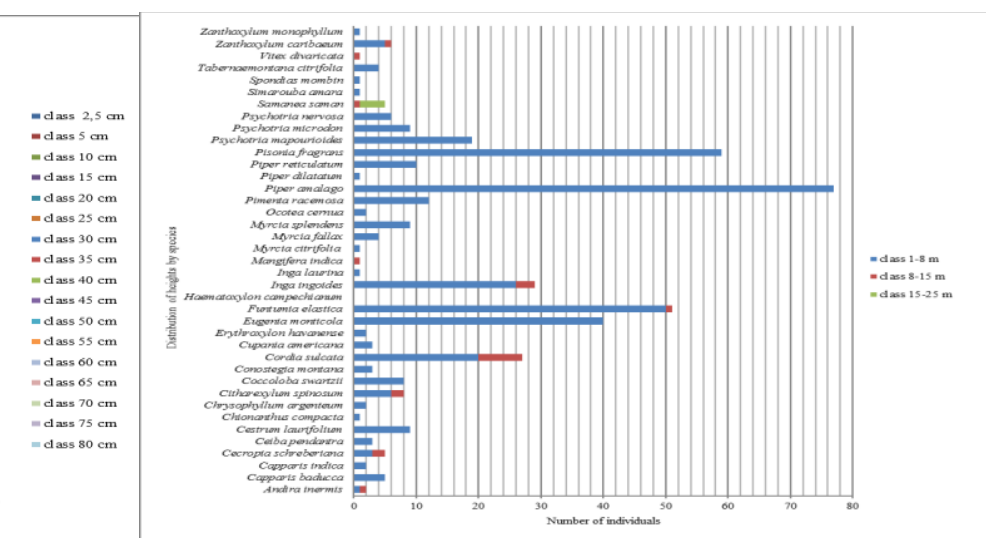

Figure 5:- - Distribution of heights

Station 2:- -Evergreen seasonal tropical forest formation (mesophilic) exhibiting average anthropization, secondarybarely structured formation $\left(825 \mathrm{~m}^{2}\right.$, Riparian terrace, Figure 1$)$.

The dominant species of this forest consisting of two strata are in order of importance Cordia sulcata and Inga ingoides (Table 2). The ecological characteristics of station 2 match those of station 1, apart from the fact that the proportion ratio between the species populations vary. The Funtumia elastica is less distributed within the quadrats (survey units), while the Cupania americana remains very marginal from a bio-demographic point of view (Figures 6 and 7).

Table 2:- - The main ecological and structural parameters of the dominant species

\begin{tabular}{|l|l|l|l|l|l|l|l|l|}
\hline Species & Families & $\begin{array}{l}\text { Absolute } \\
\text { frequency }\end{array}$ & $\begin{array}{l}\text { Relative } \\
\text { frequency }\end{array}$ & $\begin{array}{l}\text { Number of } \\
\text { individuals } \\
(*)\end{array}$ & Density & $\begin{array}{l}\text { Distributio } \\
\text { n index }\end{array}$ & $\begin{array}{l}\text { Total } \\
\text { basal area } \\
\text { by species }\end{array}$ & $\begin{array}{l}\text { Dominance } \\
\text { index }\end{array}$ \\
\hline $\begin{array}{l}\text { Cordia } \\
\text { sulcata }\end{array}$ & $\begin{array}{l}\text { Boragina } \\
\text { ceae }\end{array}$ & 10 & $91 \%$ & 108 & $\begin{array}{l}0,1309090 \\
91\end{array}$ & $\begin{array}{l}0,11900826 \\
4\end{array}$ & $\begin{array}{l}0,2737687 \\
5\end{array}$ & $\begin{array}{l}0,03258074 \\
4\end{array}$ \\
\hline $\begin{array}{l}\text { Inga } \\
\text { ingoides }\end{array}$ & $\begin{array}{l}\text { Mimosac } \\
\text { eae }\end{array}$ & 11 & $100 \%$ & 132 & 0.16 & 0.16 & 0.157 & 0,02512 \\
\hline $\begin{array}{l}\text { Dieffenbach } \\
\text { ia seguine }\end{array}$ & Araceae & 11 & $100 \%$ & 130 & $\begin{array}{l}0,1575757 \\
58\end{array}$ & $\begin{array}{l}0,15757575 \\
8\end{array}$ & 0,0637812 \\
5 & 0,01005037 \\
\hline $\begin{array}{l}\text { Samanea } \\
\text { saman }\end{array}$ & $\begin{array}{l}\text { Mimosac } \\
\text { eae }\end{array}$ & 6 & $55 \%$ & 6 & $\begin{array}{l}0,0072727 \\
27\end{array}$ & $\begin{array}{l}0,00396694 \\
2\end{array}$ & 1,62495 & $\begin{array}{l}0,00644608 \\
3\end{array}$ \\
\hline $\begin{array}{l}\text { Cordia } \\
\text { sulcata }\end{array}$ & $\begin{array}{l}\text { Boragina } \\
\text { ceae }\end{array}$ & 10 & $91 \%$ & 108 & $\begin{array}{l}0,1309090 \\
91\end{array}$ & $\begin{array}{l}0,11900826 \\
4\end{array}$ & 0,2737687 & $\begin{array}{l}0,03258074 \\
5\end{array}$ \\
\hline $\begin{array}{l}\text { Inga } \\
\text { ingoides }\end{array}$ & $\begin{array}{l}\text { Mimosac } \\
\text { eae }\end{array}$ & 11 & $100 \%$ & 132 & 0.16 & 0.16 & 0.157 & 0,02512 \\
\hline
\end{tabular}

Absolute frequency:- presence of the species in different quadrats. / Relative frequency $=$ absolute frequency / per number of quadrats $/$ Density $=$ number of individuals / station surface / Distribution index $=$ Relative frequency $x$ Density $/$ Dominance index $=$ Distribution index $\times$ Basal surface (basal area). (*):- Species apart from the regenerations 


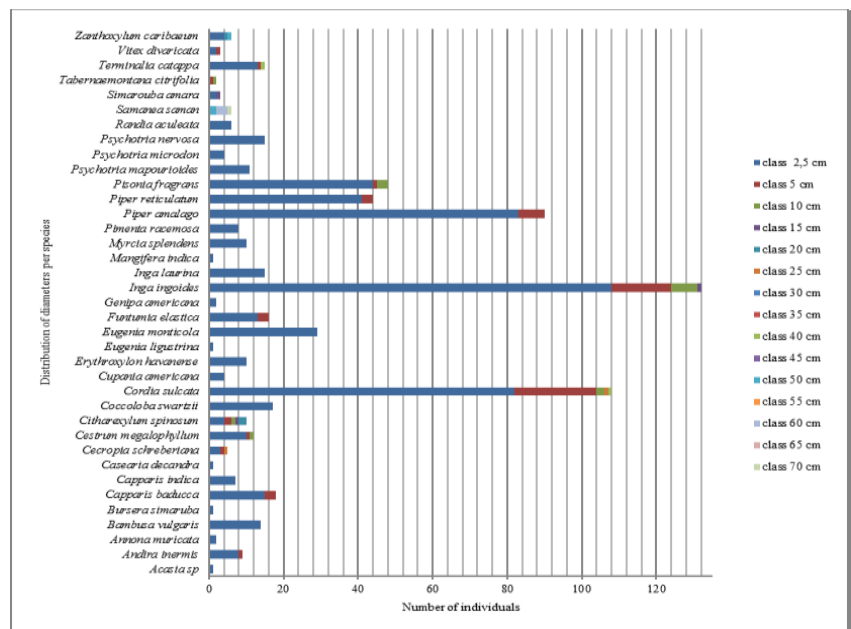

Figure 6:- - Distribution of diameters

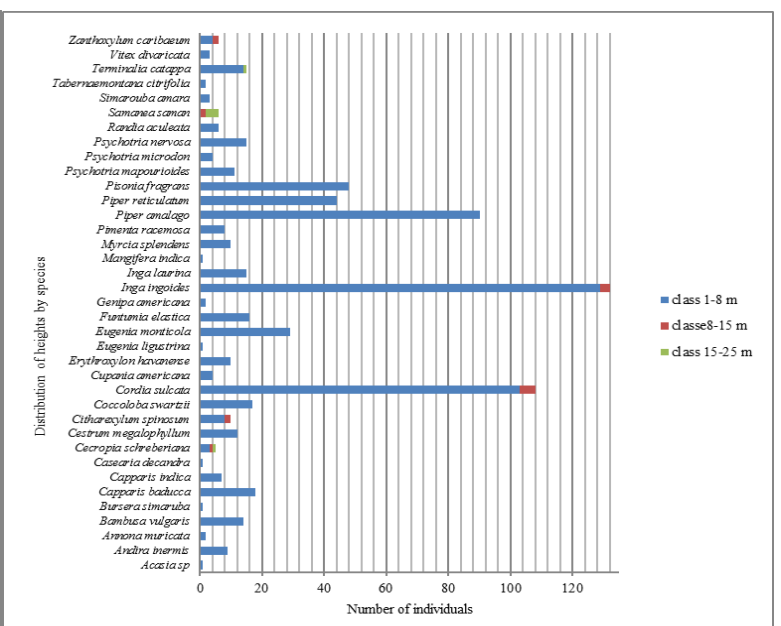

Figure 7:- - Distribution of heights

Station 3:- - Young to pre-forest forest formation to evergreen seasonal tropical lower horizon forest with recolonization xericfeatures $\left(400 \mathrm{~m}^{2}\right.$, slightly slope, Figure 1$)$.

Pimenta racemosa (Bois d'Inde) is the dominant species and has a population characterised by good site distribution and bio-demographic balance (good distribution of age classes). Together with the Pimenta racemosa, the Calliandra tergemina, Eugenia monticola and Myrcia citrifolia they represent the most widely distributed species (Table 3). This anthropized plant formation consists of eco-units belonging, by order of importance, to the shrub, pre-forest and young little stratified forest stages:- average low diameters and heights respectively between 2.5 and $5 \mathrm{~cm}$ and between 1 and $8 \mathrm{~m}$ (Figures 8 and 9). In fact, the floristic matrix consists of shrubs (Calliandratergemina) as well as specimens of tree species and regeneration trees of the later dynamic stage (Pimenta racemosa, Coccoloba swartzii, Pisonia fragrans, Bursera simaruba, Cordia sulcata, Inga laurina, Zanthoxylum caribaeum, Inga ingoides).

Table 3:- - The main ecological and structural parameters of the dominant species

\begin{tabular}{|l|l|l|l|l|l|l|l|l|}
\hline Species & Families & $\begin{array}{l}\text { Absolute } \\
\text { frequenc } \\
\text { y }\end{array}$ & $\begin{array}{l}\text { Relative } \\
\text { frequenc } \\
\text { y }\end{array}$ & $\begin{array}{l}\text { Number of } \\
\text { individuals } \\
(*)\end{array}$ & $\begin{array}{l}\text { Dens } \\
\text { ity }\end{array}$ & $\begin{array}{l}\text { Distributi } \\
\text { on index }\end{array}$ & $\begin{array}{l}\text { Total basal } \\
\text { area by } \\
\text { species }\end{array}$ & $\begin{array}{l}\text { Dominance } \\
\text { index }\end{array}$ \\
\hline $\begin{array}{l}\text { Pimenta } \\
\text { racemosa }\end{array}$ & Myrtaceae & 8 & 1 & 121 & $\begin{array}{l}0,302 \\
5\end{array}$ & 0,3025 & 0,0843875 & $\begin{array}{l}0,02552721 \\
9\end{array}$ \\
\hline $\begin{array}{l}\text { Calliandra } \\
\text { tergemina }\end{array}$ & Mimosaceae & 8 & 1 & 112 & 0.28 & 0.28 & 0,06966875 & 0,01950725 \\
\hline $\begin{array}{l}\text { Haematoxylon } \\
\text { campechianu } \\
\text { m }\end{array}$ & $\begin{array}{l}\text { Caesalpinioide } \\
\text { ae }\end{array}$ & 8 & 1 & 17 & $\begin{array}{l}0.042 \\
5\end{array}$ & 0.0425 & 0,1628875 & $\begin{array}{l}0,00692271 \\
9\end{array}$ \\
\hline $\begin{array}{l}\text { Tabebuia } \\
\text { heterophylla }\end{array}$ & Bignoniaceae & 4 & 0.5 & 16 & 0.04 & 0.02 & 0,294375 & 0,0058875 \\
\hline $\begin{array}{l}\text { Eugenia } \\
\text { monticola }\end{array}$ & Myrtaceae & 8 & 1 & 61 & $\begin{array}{l}0,152 \\
5\end{array}$ & 0,1525 & 0.0314 & 0,0047885 \\
\hline $\begin{array}{l}\text { Pisonia } \\
\text { fragrans }\end{array}$ & Nyctaginaceae & 7 & 0.875 & 17 & $\begin{array}{l}0.042 \\
5\end{array}$ & $\begin{array}{l}0,037187 \\
5\end{array}$ & $\begin{array}{l}0,07604687 \\
5\end{array}$ & 0,00282799 \\
\hline $\begin{array}{l}\text { Myrcia } \\
\text { citrifolia }\end{array}$ & Myrtaceae & 8 & 1 & 45 & $\begin{array}{l}0,112 \\
5\end{array}$ & 0,1125 & $\begin{array}{l}0,02502187 \\
5\end{array}$ & 0,00281496 \\
\hline $\begin{array}{l}\text { Coccoloba } \\
\text { swartzii }\end{array}$ & Polygonaceae & 7 & 0.875 & 25 & $\begin{array}{l}0.062 \\
0\end{array}$ & $\begin{array}{l}0,054687 \\
5\end{array}$ & $\begin{array}{l}0,03385312 \\
5\end{array}$ & 0,00185134 \\
\hline
\end{tabular}

Absolute frequency:- presence of the species in different quadrats. / Relative frequency $=$ absolute frequency / per number of quadrats $/$ Density $=$ number of individuals $/$ station surface / Distribution index $=$ Relative frequency $x$ Density / Dominance index $=$ Distribution index $\times$ Basal surface (basal area). (*):- Species apart from the regenerations 


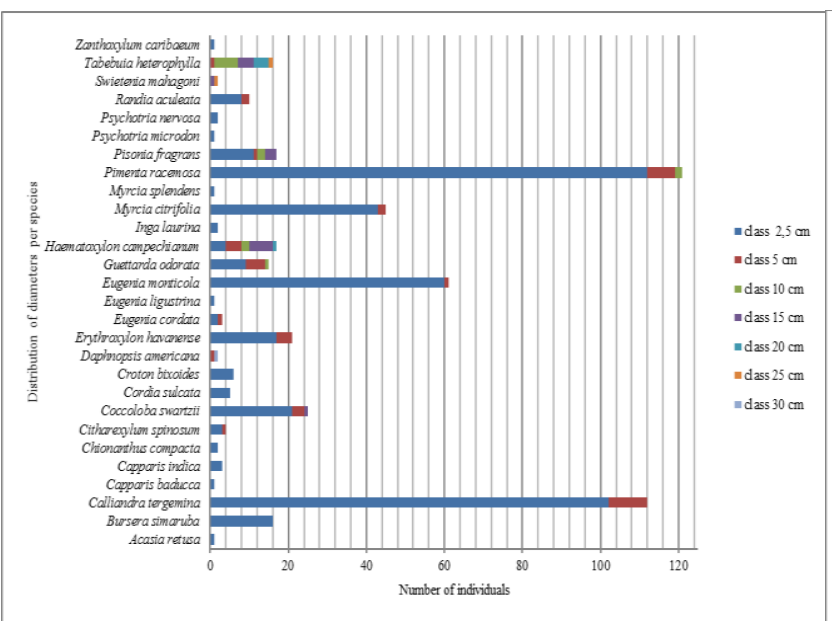

Figure 8: - - Distribution of diameters

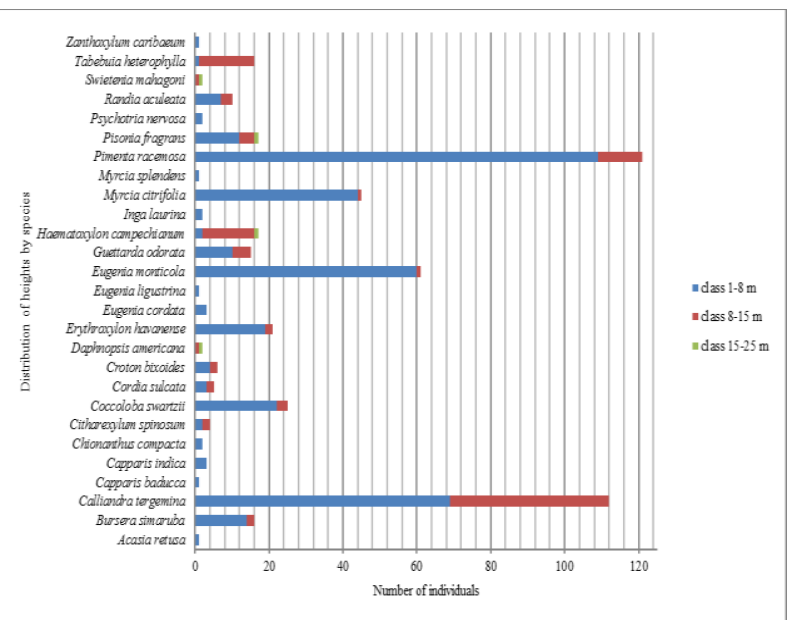

Figure 9:- - Distribution of heights

Station 4:- Evergreen seasonal tropical lower horizon floristic unit with Xeric characteristics in the mature shrub stage $\left(450 \mathrm{~m}^{2}\right.$, Figure 1$)$.

This anthropized plant community is dominated by a Eugenia monticola population with small sections (mostly between 2.2 and $5 \mathrm{~cm}$, Figure 10). The Eugenia monticola population in morphogenetic expansion (morphological growth)associated with that of Calliandra tergemina form a dense low matrix (mainly between 1 and 8 meters, Figure 10) where species such as Pisonia fragrans (Mapou) and Pimenta racemosa (Bois d'Inde) regenerate in a later stage. A few mature Courbaril specimens (Hymenaea courbaril Figures 10 and 11) are relics of a former forest more advanced from the point of view of vegetation dynamics.

Table 4:- - The main ecological and structural parameters of the dominant species

\begin{tabular}{|c|c|c|c|c|c|c|c|c|}
\hline Species & Families & $\begin{array}{l}\text { Absolute } \\
\text { frequency }\end{array}$ & $\begin{array}{l}\text { Relative } \\
\text { frequenc } \\
\mathrm{y}\end{array}$ & $\begin{array}{l}\text { Number of } \\
\text { individuals } \\
(*)\end{array}$ & Density & $\begin{array}{l}\text { Distribution } \\
\text { index }\end{array}$ & $\begin{array}{lr}\text { Total basal } \\
\text { area by } \\
\text { species }\end{array}$ & $\begin{array}{l}\text { Dominance } \\
\text { index }\end{array}$ \\
\hline $\begin{array}{l}\text { Eugenia } \\
\text { monticola }\end{array}$ & Myrtaceae & 9 & $100 \%$ & 162 & 0.36 & 0.36 & 0,27965625 & 0,10067625 \\
\hline $\begin{array}{l}\text { Pisonia } \\
\text { fragrans }\end{array}$ & $\begin{array}{l}\text { Nyctaginac } \\
\text { eae }\end{array}$ & 9 & $100 \%$ & 54 & 0.12 & 0.12 & 0,35619375 & 0,04274325 \\
\hline $\begin{array}{l}\text { Calliandr } \\
a \\
\text { tergemina }\end{array}$ & $\begin{array}{l}\text { Mimosacea } \\
\mathrm{e}\end{array}$ & 7 & $78 \%$ & 123 & $\begin{array}{l}0,2733333 \\
3\end{array}$ & $\begin{array}{l}0,21259259 \\
3\end{array}$ & 0,16485 & $\begin{array}{l}0,03504588 \\
9\end{array}$ \\
\hline $\begin{array}{l}\text { Pimenta } \\
\text { racemosa }\end{array}$ & Myrtaceae & 9 & $100 \%$ & 70 & $\begin{array}{l}0,1555555 \\
6\end{array}$ & $\begin{array}{l}0,15555555 \\
6\end{array}$ & $\begin{array}{l}0,18594687 \\
5\end{array}$ & $\begin{array}{l}0,02892506 \\
9\end{array}$ \\
\hline
\end{tabular}

Absolute frequency:- presence of the species in different quadrats. / Relative frequency = absolute frequency / per number of quadrats $/$ Density $=$ number of individuals $/$ station surface $/$ Distribution index $=$ Relative frequency $\times$ Density $/$ Dominance index $=$ Distribution index $\times$ Basal surface (basal area). (*):- Species apart from the regenerations 


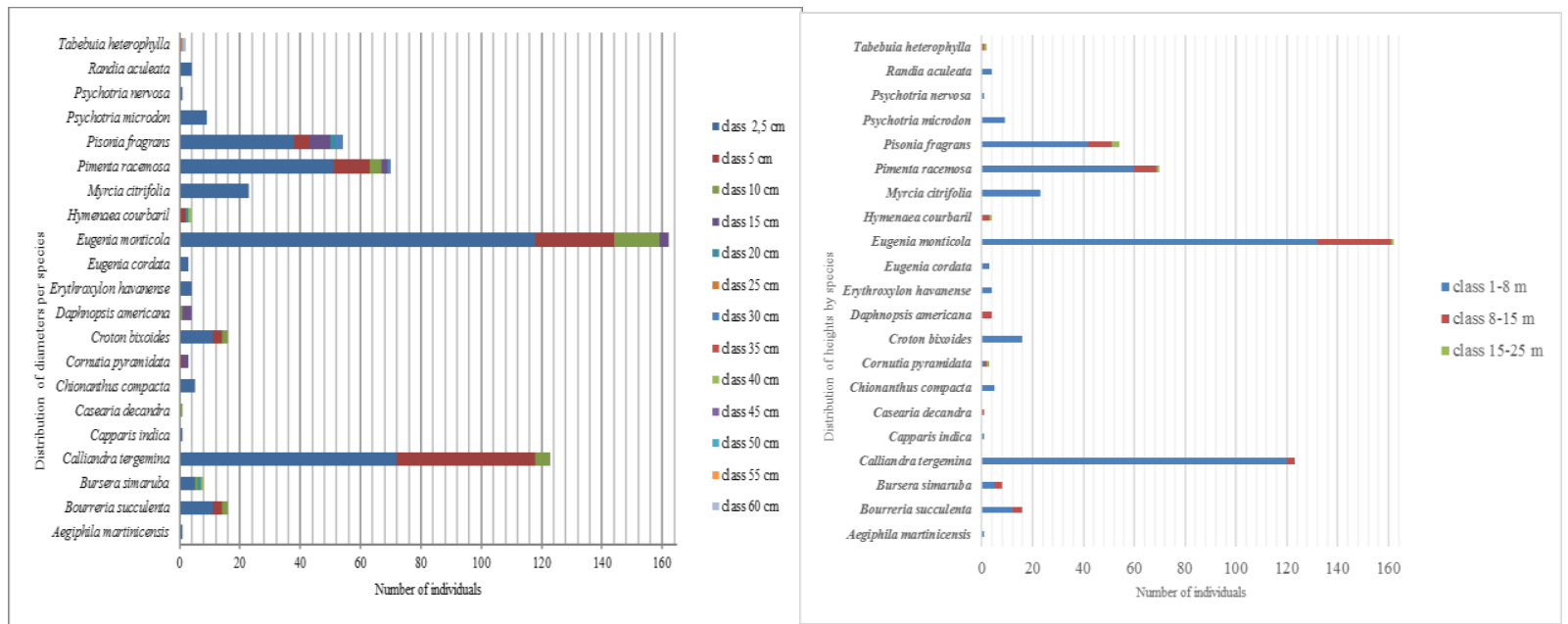

Figure 10:- -Distribution of diametersFigure 11:- - Distribution of heights

Station 5:- Evergreen seasonal tropical lower horizon floristic unit with Xeric characteristics in the mature shrub stage $\left(400 \mathrm{~m}^{2}\right.$, Figure 1).

The Calliandratergemina (Bois Patate) forms a virtually pure matrix where or in which we find tree species of the later phases of vegetation dynamics such as:- Coccoloba swartzii, Guettarda odorata, Chionanthus compacta, Pimenta racemosa, Pisonia fragrans. The diameters and heights of the individuals are, for the most part, low or very low (Figures 12 and 13).

Table 5:- - The main ecological and structural parameters of the dominant species

\begin{tabular}{|l|l|l|l|l|l|l|l|l|}
\hline Species & Families & $\begin{array}{l}\text { Absolute } \\
\text { frequency }\end{array}$ & $\begin{array}{l}\text { Relative } \\
\text { frequenc } \\
\mathrm{y}\end{array}$ & $\begin{array}{l}\text { Number of } \\
\text { individuals } \\
(*)\end{array}$ & $\begin{array}{l}\text { Densit } \\
\mathrm{y}\end{array}$ & $\begin{array}{l}\text { Distributio } \\
\mathrm{n} \text { index }\end{array}$ & $\begin{array}{l}\text { Total basal } \\
\text { area by bominance } \\
\text { species }\end{array}$ & $\begin{array}{l}\text { Dom } \\
\text { index }\end{array}$ \\
\hline $\begin{array}{l}\text { Calliandra } \\
\text { tergemina }\end{array}$ & $\begin{array}{l}\text { Mimosacea } \\
\mathrm{e}\end{array}$ & 8 & $100 \%$ & 192 & 0.48 & 0.48 & 0,32086875 & 0,154017 \\
\hline $\begin{array}{l}\text { Haematoxylon } \\
\text { campechianu } \\
\mathrm{m}\end{array}$ & $\begin{array}{l}\text { Caesalpinio } \\
\text { ideae }\end{array}$ & 8 & $100 \%$ & 17 & 0.0425 & 0.0425 & 0,62015 & $\begin{array}{l}0,02635637 \\
5\end{array}$ \\
\hline $\begin{array}{l}\text { Eugenia } \\
\text { monticola }\end{array}$ & Myrtaceae & 8 & $100 \%$ & 64 & 0.16 & 0.16 & $\begin{array}{l}0,06230937 \\
5\end{array}$ & 0,0099695 \\
\hline $\begin{array}{l}\text { Coccoloba } \\
\text { swartzii }\end{array}$ & $\begin{array}{l}\text { Polygonace } \\
\text { ae }\end{array}$ & 5 & $63 \%$ & 18 & 0.045 & 0,028125 & $\begin{array}{l}0,35275937 \\
5\end{array}$ & 0,00992135 \\
7
\end{tabular}

Absolute frequency:- presence of the species in different quadrats. / Relative frequency $=$ absolute frequency / per number of quadrats $/$ Density $=$ number of individuals $/$ station surface / Distribution index $=$ Relative frequency $x$ Density / Dominance index $=$ Distribution index $\times$ Basal surface (basal area). (*):- Species apart from the regenerations 


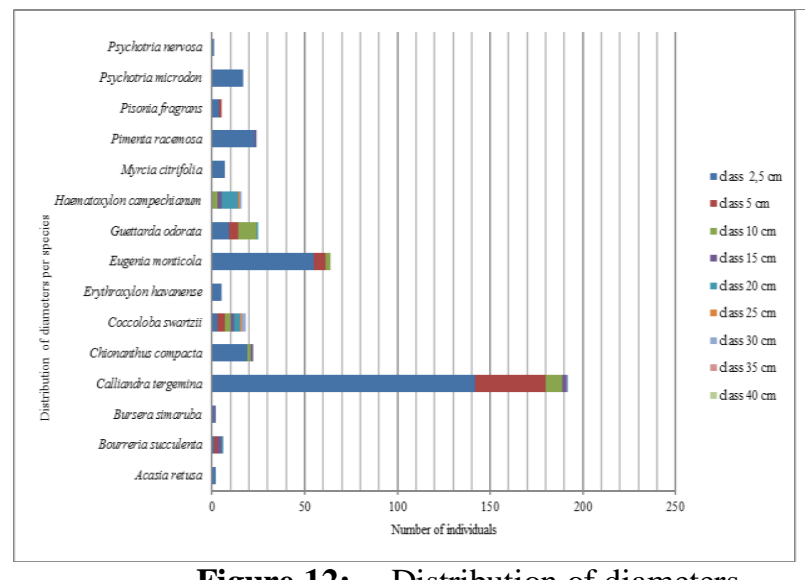

Figure 12:- - Distribution of diameters

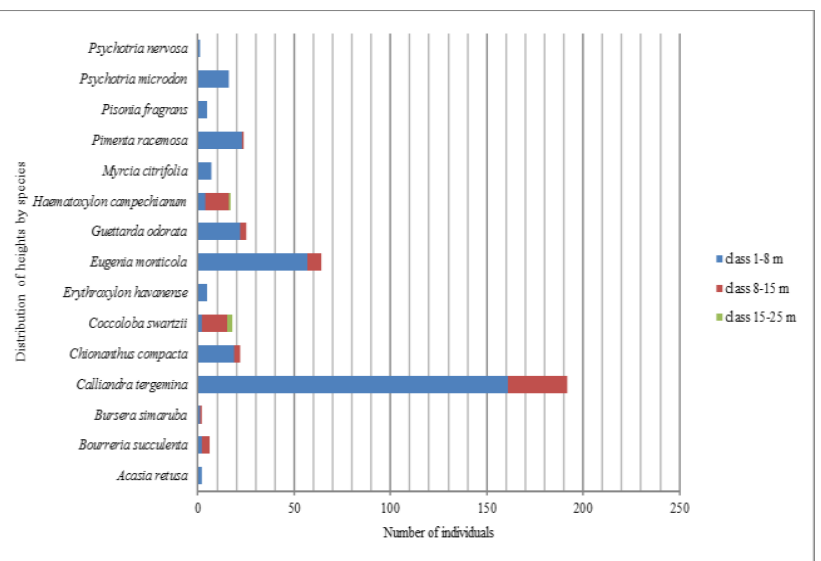

Figure 13:- - Distribution of heights

Station 6:- Evergreen seasonal type forest formation in the secondary forest stage $\left(1000 \mathrm{~m}^{2}\right.$, Riparian terrace, Figure 1).

Funtumia elastica is the allochthonous speciesin most competition in relation to the biophysical factors and is present in all quadrats(Figure 14). In addition, the age classes show an almost balanced distribution. In general, other species have lower distribution indices and basal surfaces. These result from the dominance of sections and heights which distinctively and essentially range between 2.5 and $5 \mathrm{~cm}$ and between 1 and $8 \mathrm{~m}$ (Figures 14 and 15).

Table 6:- - The main ecological and structural parameters of the dominant species

\begin{tabular}{|c|c|c|c|c|c|c|c|c|}
\hline Species & Families & $\begin{array}{l}\text { Absolute } \\
\text { frequenc } \\
\mathrm{y}\end{array}$ & $\begin{array}{l}\text { Relative } \\
\text { frequenc } \\
\mathrm{y}\end{array}$ & $\begin{array}{l}\text { Number of } \\
\text { individual } \\
\mathrm{s}(*)\end{array}$ & $\begin{array}{l}\text { Densit } \\
\mathrm{y}\end{array}$ & $\begin{array}{l}\text { Distributio } \\
\mathrm{n} \text { index }\end{array}$ & $\begin{array}{lr}\text { Total basal } \\
\text { area } & \text { by } \\
\text { species } & \\
\end{array}$ & $\begin{array}{l}\text { Dominance } \\
\text { index }\end{array}$ \\
\hline $\begin{array}{l}\text { Funtumi } \\
\text { a elastica }\end{array}$ & $\begin{array}{l}\text { Apocynacea } \\
\mathrm{e}\end{array}$ & 10 & $100 \%$ & 251 & 0.251 & 0.251 & 0,3611 & 0,0906361 \\
\hline $\begin{array}{l}\text { Inga } \\
\text { ingoides }\end{array}$ & Mimosaceae & 10 & $100 \%$ & 22 & 0.022 & 0.022 & $\begin{array}{l}1,02197187 \\
5\end{array}$ & $\begin{array}{l}0,02248338 \\
1\end{array}$ \\
\hline
\end{tabular}

Absolute frequency:- presence of the species in different quadrats. / Relative frequency $=$ absolute frequency / per number of quadrats $/$ Density $=$ number of individuals $/$ station surface / Distribution index $=$ Relative frequency $x$ Density $/$ Dominance index $=$ Distribution index $\times$ Basal surface (basal area). $(*):-$ Species apart from the regenerations.

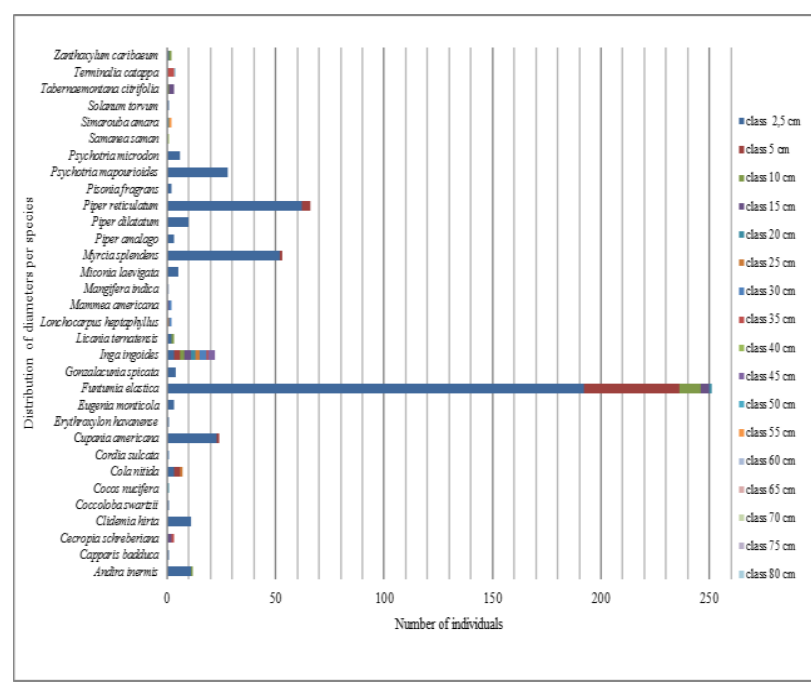

Figure 14:- -Distribution of diameters

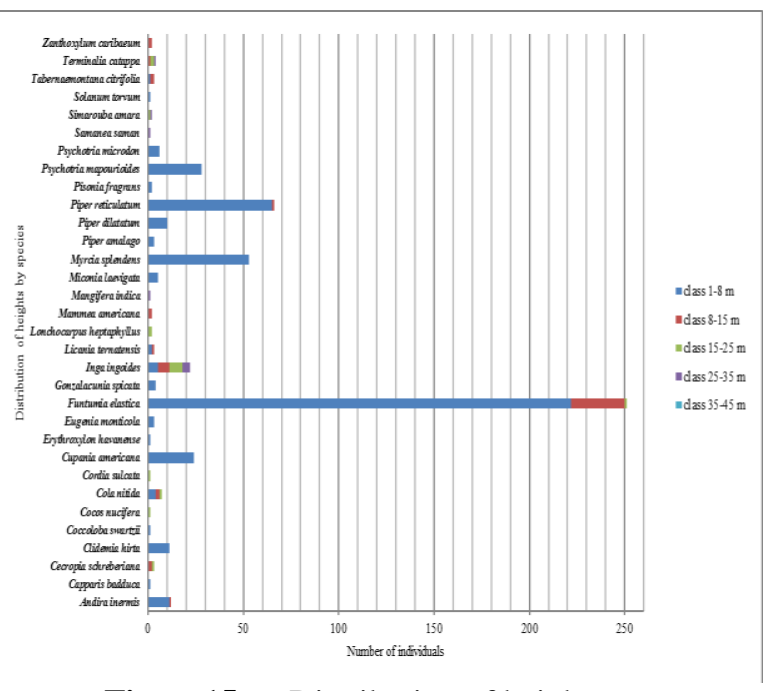

Figure15:- - Distribution of heights 
Station 7:- -This seasonal tropical evergreen phytocenosis type forest is composed of eco-units corresponding to the shrub, pre-forest and secondary forest stages $\left(450 \mathrm{~m}^{2}\right.$, Figure 1$)$.

The predominant formation consist of three species (Myrcia splendens, Inga ingoides and Funtumia elastica) and, here and there we also see individuals with different basal areas and stratigraphic status (Figures 16 and 17), species of the understory, middle and upper strata).

Table 7:- - The main ecological and structural parameters of the dominant species

\begin{tabular}{|c|c|c|c|c|c|c|c|c|}
\hline Species & Families & $\begin{array}{l}\text { Absolute } \\
\text { frequenc } \\
\mathrm{y}\end{array}$ & $\begin{array}{l}\text { Relative } \\
\text { frequenc } \\
\mathrm{y}\end{array}$ & $\begin{array}{l}\text { Number } \\
\text { of } \\
\text { individual } \\
\mathrm{s}(*)\end{array}$ & Density & $\begin{array}{l}\text { Distribution } \\
\text { index }\end{array}$ & $\begin{array}{lr}\text { Total basal } \\
\text { area } \\
\text { species }\end{array}$ & $\begin{array}{l}\text { Dominance } \\
\text { index }\end{array}$ \\
\hline $\begin{array}{l}\text { Myrcia } \\
\text { splenden } \\
\text { s }\end{array}$ & Myrtaceae & 9 & 1 & 143 & $\begin{array}{l}0,31777777 \\
8\end{array}$ & $\begin{array}{l}0,31777777 \\
8\end{array}$ & 0,09910625 & $\begin{array}{l}0,03149376 \\
4\end{array}$ \\
\hline $\begin{array}{l}\text { Inga } \\
\text { ingoides }\end{array}$ & $\begin{array}{l}\text { Mimosacea } \\
\mathrm{e}\end{array}$ & 8 & 0.889 & 34 & $\begin{array}{l}0,07555555 \\
6\end{array}$ & $\begin{array}{l}0,06716049 \\
4\end{array}$ & $\begin{array}{l}0,22029062 \\
5\end{array}$ & $\begin{array}{l}0,01479482 \\
7\end{array}$ \\
\hline $\begin{array}{l}\text { Funtumi } \\
a \\
\text { elastica }\end{array}$ & $\begin{array}{l}\text { Apocynacea } \\
\mathrm{e}\end{array}$ & 9 & 1 & 60 & $\begin{array}{l}0,13333333 \\
3\end{array}$ & $\begin{array}{l}0,13333333 \\
3\end{array}$ & 0,05396875 & $\begin{array}{l}0,00719583 \\
3\end{array}$ \\
\hline
\end{tabular}

Absolute frequency:- presence of the species in different quadrats. / Relative frequency $=$ absolute frequency / per number of quadrats $/$ Density $=$ number of individuals / station surface / Distribution index $=$ Relative frequency $x$ Density $/$ Dominance index $=$ Distribution index $\times$ Basal surface (basal area). $(*)$ :- Species apart from the regenerations.

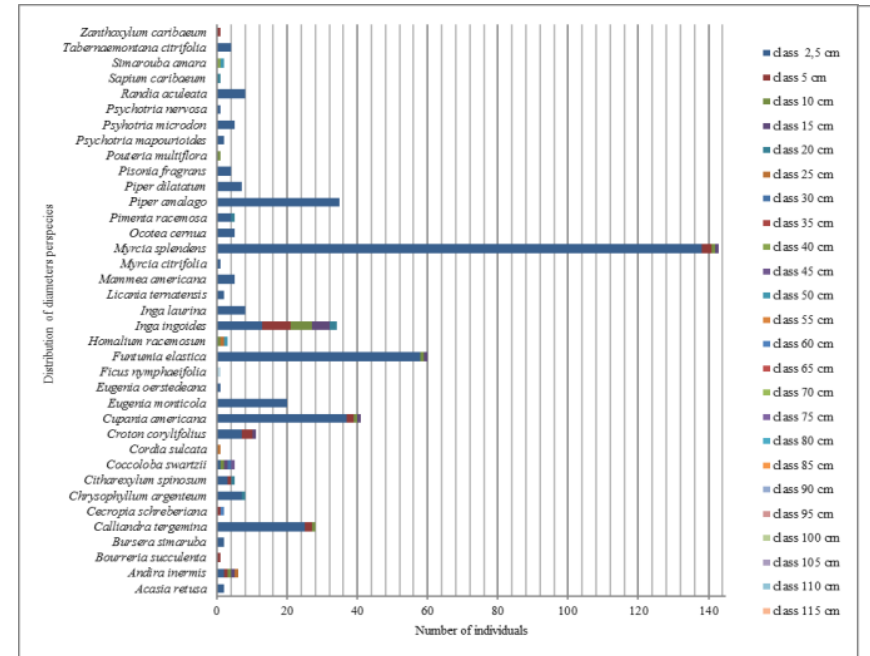

Figure 16:- - Distribution of diameters

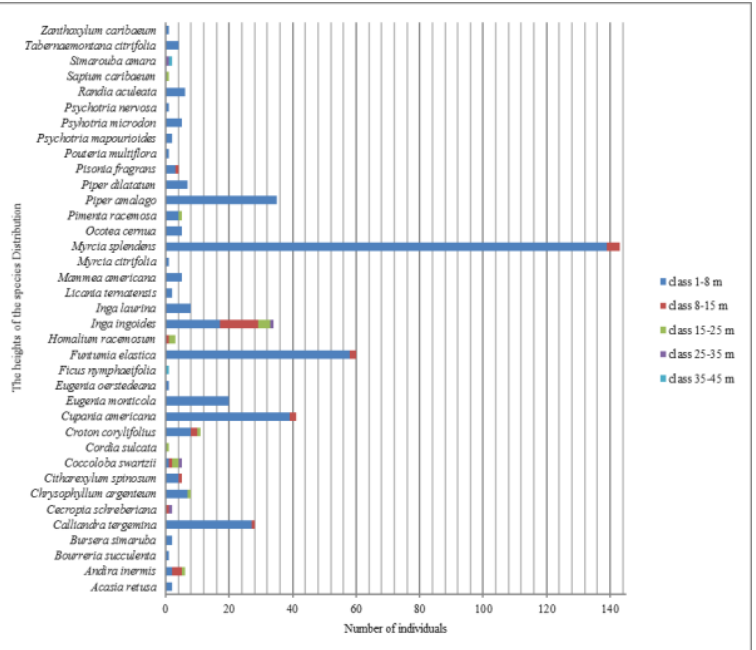

Figure 17:- Distribution of heights

Station 8:- -Forest formation with a lot of similarity with the previous one, despite the fact that from an ecological point of view the dominant formation is a little different $\left(600 \mathrm{~m}^{2}\right.$, Figure 1$)$.

In order of importance we see Myrcia splendens, Simarouba amara, Andira inermis, Sapium caribaeum. The structure of diameters and heights of this formation consisting of shrub, pre-forest and young forest units results mainly from the recurrent disturbances due to Man's actions. The majority of individuals have weak sections (between 2.5 and $5 \mathrm{~cm}$ ) and rise to heights between 1 and $8 \mathrm{~m}$ (Figures 18 and 19). 
Table 8:- - The main ecological and structural parameters of the dominant species

\begin{tabular}{|c|c|c|c|c|c|c|c|c|}
\hline Species & Families & $\begin{array}{l}\text { Absolute } \\
\text { frequenc } \\
\mathrm{y}\end{array}$ & $\begin{array}{l}\text { Relative } \\
\text { frequenc } \\
\mathrm{y}\end{array}$ & $\begin{array}{l}\text { Number } \\
\text { of } \\
\text { individua } \\
\text { ls }(*)\end{array}$ & Density & $\begin{array}{l}\text { Distributio } \\
\mathrm{n} \text { index }\end{array}$ & $\begin{array}{l}\text { Total basal } \\
\text { area by } \\
\text { species }\end{array}$ & $\begin{array}{l}\text { Dominance } \\
\text { index }\end{array}$ \\
\hline $\begin{array}{l}\text { Myrcia } \\
\text { splendens }\end{array}$ & Myrtaceae & 12 & $100 \%$ & 314 & $\begin{array}{l}0,52333333 \\
3\end{array}$ & $\begin{array}{l}0,52333333 \\
3\end{array}$ & $\begin{array}{l}0,25169062 \\
5\end{array}$ & $\begin{array}{l}0,13171809 \\
4\end{array}$ \\
\hline $\begin{array}{l}\text { Simaroub } \\
\text { a amara }\end{array}$ & $\begin{array}{l}\text { Simaroubace } \\
\text { ae }\end{array}$ & 9 & $75 \%$ & 74 & $\begin{array}{l}0,12333333 \\
3\end{array}$ & 0,0925 & 1,0538625 & $\begin{array}{l}0,09748228 \\
1\end{array}$ \\
\hline $\begin{array}{l}\text { Andirá } \\
\text { inermis }\end{array}$ & Fabaceae & 11 & $92 \%$ & 31 & $\begin{array}{l}0,05166666 \\
7\end{array}$ & $\begin{array}{l}0,04736111 \\
1\end{array}$ & 0,993025 & $\begin{array}{l}0,04703076 \\
7\end{array}$ \\
\hline $\begin{array}{l}\text { Sapium } \\
\text { caribaeu } \\
m\end{array}$ & $\begin{array}{l}\text { Euphorbiacea } \\
\text { e }\end{array}$ & 7 & $58 \%$ & 24 & 0.04 & $\begin{array}{l}0,02333333 \\
3\end{array}$ & 1,1794625 & $\begin{array}{l}0,02752079 \\
2\end{array}$ \\
\hline
\end{tabular}

Absolute frequency:- presence of the species in different quadrats. / Relative frequency $=$ absolute frequency / per number of quadrats $/$ Density $=$ number of individuals $/$ station surface $/$ Distribution index $=$ Relative frequency $x$ Density $/$ Dominance index $=$ Distribution index $\times$ Basal surface (basal area). $(*):-$ Species apart from the regenerations.

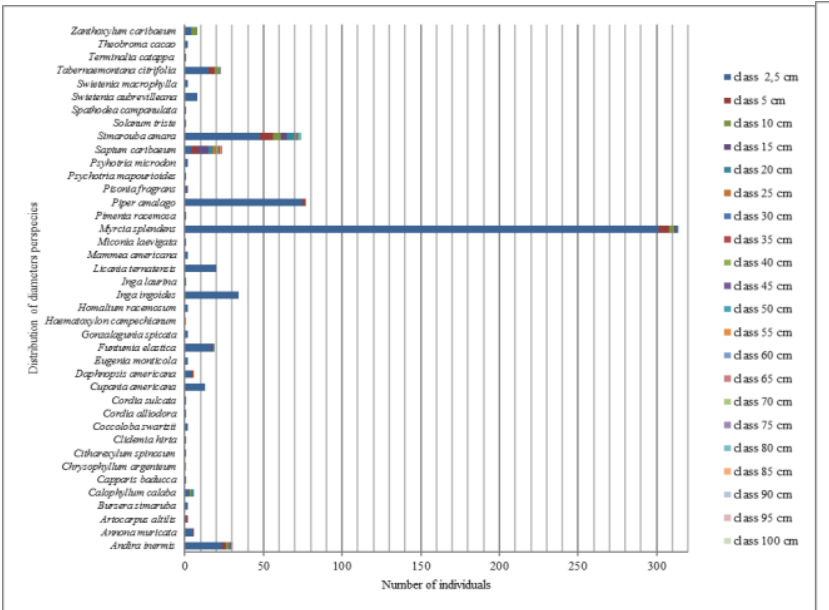

Figure 18:- - Distribution of diameters

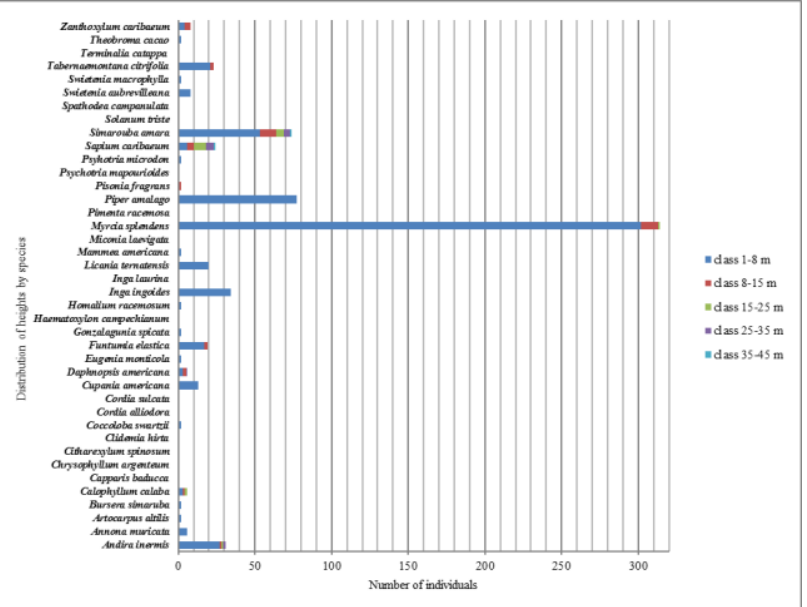

Figure 19:- - Distribution of heights

Station 9:- - Seasonal evergreen lower horizon forest formation with and xeric characteristics $\left(800 \mathrm{~m}^{2}\right.$, Figure 1).

This plant association is dominated by the Eugenia monticola population joined in varying proportions by mature plant species, in morphogenetic regeneration and expansion (in development). Ocotea coriacea, Pimenta racemosa, Pisonia fragrans, Coccoloba swartzii, Lonchocarpus punctatus. We also mention the presence of Brosimum alicastrum:- extremely rare species of the Moraceae family. Individuals of low diameters are preponderant and Eugenia monticola, Ocotea coriacea, Pimenta racemosa and Coccoloba swartzii seem to have an almost balanced diameter class distribution (Figures 20 and 21). 
Table 9:- - The main ecological and structural parameters of the dominant species

\begin{tabular}{|c|c|c|c|c|c|c|c|c|}
\hline Species & Families & $\begin{array}{l}\text { Absolute } \\
\text { frequenc } \\
\mathrm{y}\end{array}$ & $\begin{array}{l}\text { Relative } \\
\text { frequenc } \\
\mathrm{y}\end{array}$ & $\begin{array}{l}\text { Number } \\
\text { of } \\
\text { individual } \\
\mathrm{s}(*)\end{array}$ & $\begin{array}{l}\text { Densit } \\
\mathrm{y}\end{array}$ & $\begin{array}{l}\text { Distributio } \\
\mathrm{n} \text { index }\end{array}$ & $\begin{array}{l}\text { Total basal } \\
\text { area by } \\
\text { species }\end{array}$ & $\begin{array}{l}\text { Dominance } \\
\text { index }\end{array}$ \\
\hline $\begin{array}{l}\text { Eugenia } \\
\text { monticola }\end{array}$ & Myrtaceae & 8 & $100 \%$ & 383 & $\begin{array}{l}0,4787 \\
5\end{array}$ & 0,47875 & $\begin{array}{l}0,61573437 \\
5\end{array}$ & $\begin{array}{l}0,29478283 \\
2\end{array}$ \\
\hline $\begin{array}{l}\text { Ocotea } \\
\text { coriacea }\end{array}$ & Lauraceae & 8 & $100 \%$ & 193 & $\begin{array}{l}0,2412 \\
5\end{array}$ & 0,24125 & 0,247275 & $\begin{array}{l}0,05965509 \\
4\end{array}$ \\
\hline $\begin{array}{l}\text { Pimenta } \\
\text { racemosa }\end{array}$ & Myrtaceae & 8 & $100 \%$ & 28 & 0.035 & 0.035 & $\begin{array}{l}0,66577812 \\
5\end{array}$ & $\begin{array}{l}0,02330223 \\
4\end{array}$ \\
\hline $\begin{array}{l}\text { Pisonia } \\
\text { fragrans }\end{array}$ & $\begin{array}{l}\text { Nyctaginacea } \\
\mathrm{e}\end{array}$ & 8 & $100 \%$ & 11 & $\begin{array}{l}0.0137 \\
5\end{array}$ & 0.01375 & $\begin{array}{l}0,73152187 \\
5\end{array}$ & $\begin{array}{l}0,01005842 \\
6\end{array}$ \\
\hline $\begin{array}{l}\text { Coccoloba } \\
\text { swartzii }\end{array}$ & $\begin{array}{l}\text { Polygonacea } \\
\text { e }\end{array}$ & 6 & $75 \%$ & 21 & $\begin{array}{l}0,0262 \\
5\end{array}$ & 0,0196875 & 0,38465 & $\begin{array}{l}0,00757279 \\
7\end{array}$ \\
\hline $\begin{array}{l}\text { Lonchocarpu } \\
\text { s punctatus }\end{array}$ & Fabaceae & 3 & $38 \%$ & 8 & 0.01 & 0,00375 & 0,788925 & $\begin{array}{l}0,00295846 \\
9\end{array}$ \\
\hline
\end{tabular}

Absolute frequency:- presence of the species in different quadrats. / Relative frequency $=$ absolute frequency / per number of quadrats $/$ Density $=$ number of individuals $/$ station surface $/$ Distribution index $=$ Relative frequency $\times$ Density / Dominance index $=$ Distribution index $\times$ Basal surface (basal area). $(*)$ :- Species apart from the regenerations

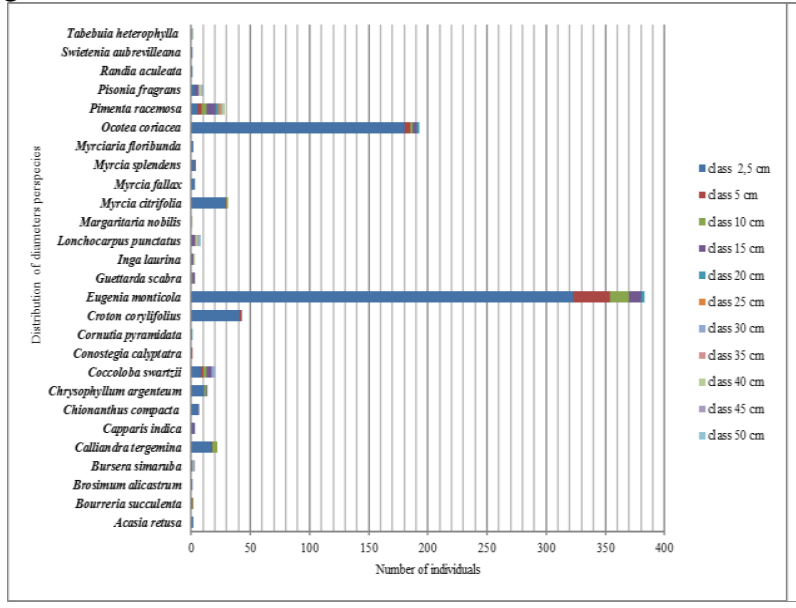

Figure 20:- - Distribution of diameters

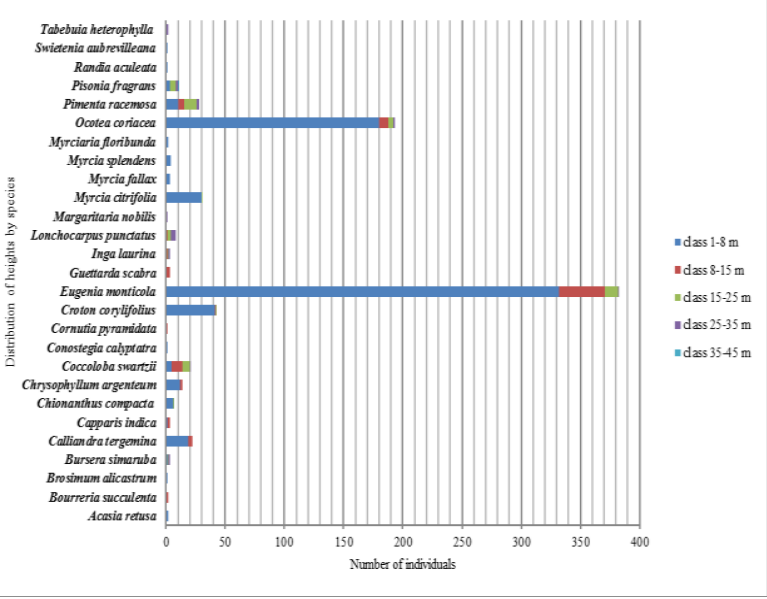

Figure 21:- -Distribution of heights

Station 10:- -Secondary tropical seasonal evergreen forest formation $\left(\mathbf{8 0 0} \mathbf{~ m}^{2}\right.$, Figure 1).

The populations of species that comprise this tropical seasonal evergreen forest floristic association are sparse and also exhibit low cumulative basal surfaces. The heights and diameters range mainly in the first classes:- 2.5 to $5 \mathrm{~cm}$ for the sections and 1 to $8 \mathrm{~m}$ for the heights (Figures 22 and 23). The Cupania americana is the only species that dominates from an ecological point of view through a distribution index well above that of other species. We must mention the existence of very strong installation (seedlings and regeneration) of Brosimum alicastrum.

Table 10:- - The main ecological and structural parameters of the dominant species

\begin{tabular}{|l|l|l|l|l|l|l|l|l|}
\hline Species & Families & $\begin{array}{l}\text { Absolute } \\
\text { frequenc } \\
\mathrm{y}\end{array}$ & $\begin{array}{l}\text { Relative } \\
\text { frequenc } \\
\mathrm{y}\end{array}$ & $\begin{array}{l}\text { Number } \\
\text { of } \\
\text { individual } \\
\mathrm{s}(*)\end{array}$ & Density & $\begin{array}{l}\text { Distributio } \\
\mathrm{n} \text { index }\end{array}$ & $\begin{array}{l}\text { Total basal } \\
\text { area } \\
\text { species }\end{array}$ & $\begin{array}{l}\text { Dominance } \\
\text { index }\end{array}$ \\
\hline $\begin{array}{l}\text { Cupania } \\
\text { americana }\end{array}$ & Sapindaceae & 8 & $100 \%$ & 63 & $\begin{array}{l}0.0787 \\
5\end{array}$ & 0.07875 & $\begin{array}{l}0,3640437 \\
5\end{array}$ & $\begin{array}{l}0,02866844 \\
5\end{array}$ \\
\hline $\begin{array}{l}\text { Simaroub } \\
\text { a amara }\end{array}$ & $\begin{array}{l}\text { Simaroubacea } \\
\mathrm{e}\end{array}$ & 7 & $88 \%$ & 22 & 0.0275 & 0,0240625 & 0,945925 & 0,02276132 \\
\hline
\end{tabular}


Absolute frequency:- presence of the species in different quadrats. / Relative frequency $=$ absolute frequency / per number of quadrats $/$ Density $=$ number of individuals $/$ station surface $/$ Distribution index $=$ Relative frequency $x$ Density $/$ Dominance index $=$ Distribution index $\times$ Basal surface (basal area). (*):- Species apart from the regenerations.

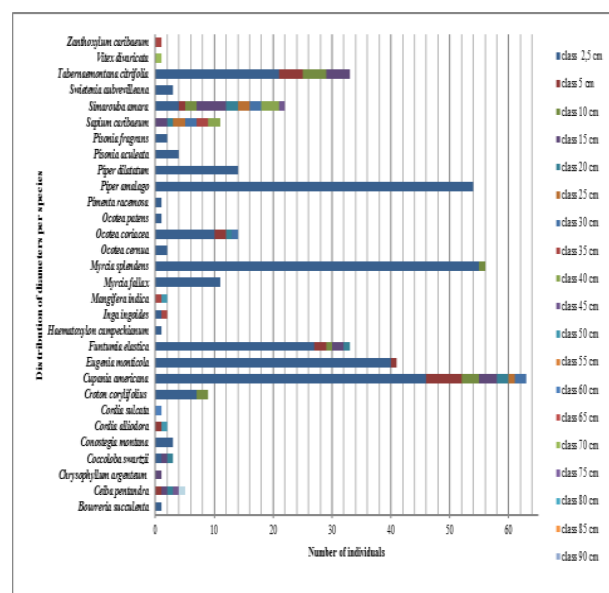

Figure 22:- - Distribution of diameters

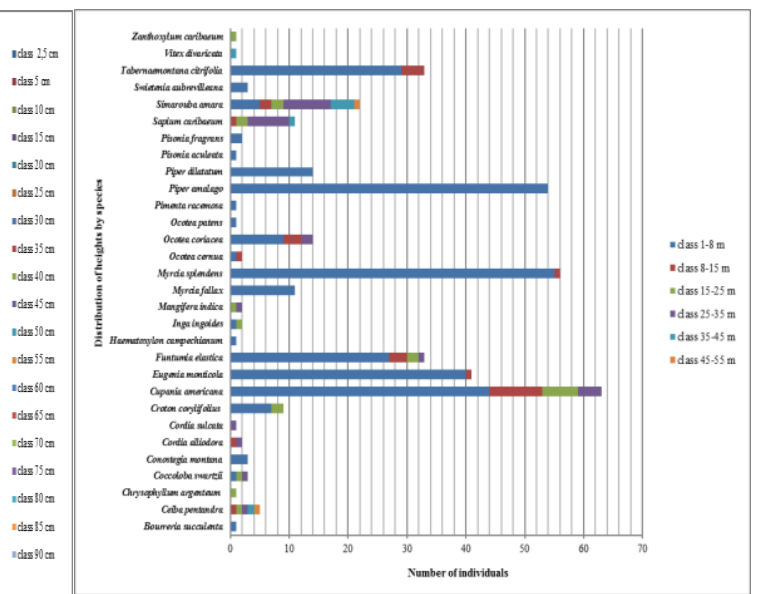

Figure 23:- - Distribution of heights

Station 11:- -Tropical seasonal evergreen forest formation on a slope exposed to the wind, in the pre-forest to young foreststage $\left(500 \mathrm{~m}^{2}\right.$, Figure 1)

The same above mentioned conclusions are also valid here except that the collection of species (the floristic potential) and the predominant floral formations are not identical. Myrcia citrifolia forms a matrix within which we find by order of dominance:- Guettarda scabra, Coccoloba swartzii Cornutia pyramidata, Bursera simaruba, Eugenia monticola Bourreria succulenta, Croton corylifolius and Pimenta racemosa. No species populations is truly a balanced structure. This happens both at the level of diameters as heights. For the latter, the majority classes are respectively 2.5 to $5 \mathrm{~cm}$ and 1 to $8 \mathrm{~m}$ (Figures 24 and 25).All these taxa are post-pioneer ones, except Pimenta racemosa which settles very early in the plant succession and participates in all the phases of intra-forest evolution until the climax with notable demographic variations.

Table 11:- - The main ecological and structural parameters dominant species

\begin{tabular}{|l|l|l|l|l|l|l|l|l|}
\hline Species & Families & $\begin{array}{l}\text { Absolute } \\
\text { frequency }\end{array}$ & $\begin{array}{l}\text { Relative } \\
\text { frequency }\end{array}$ & $\begin{array}{l}\text { Number of } \\
\text { individuals } \\
(*)\end{array}$ & Density & $\begin{array}{l}\text { Distribution } \\
\text { index }\end{array}$ & $\begin{array}{l}\text { Total basal } \\
\text { area } \\
\text { species }\end{array}$ & $\begin{array}{l}\text { Dominance } \\
\text { index }\end{array}$ \\
\hline $\begin{array}{l}\text { Myrcia } \\
\text { citrifolia }\end{array}$ & Myrtaceae & 10 & $100 \%$ & 168 & 0.336 & 0.336 & 0,0942 & 0,0316512 \\
\hline $\begin{array}{l}\text { Guettarda } \\
\text { scabra }\end{array}$ & Rubiaceae & 7 & $70 \%$ & 62 & 0.124 & 0.0868 & 0,2884875 & 0,025040715 \\
\hline $\begin{array}{l}\text { Cornutia } \\
\text { pyramidata }\end{array}$ & Verbenaceae & 6 & $60 \%$ & 19 & 0.038 & 0,0228 & 0,8340625 & 0,019016625 \\
\hline $\begin{array}{l}\text { Coccoloba } \\
\text { swartzii }\end{array}$ & Polygonaceae & 10 & $100 \%$ & 38 & 0.076 & 0.076 & 0,248746875 & 0,018904763 \\
\hline $\begin{array}{l}\text { Eugenia } \\
\text { monticola }\end{array}$ & Myrtaceae & 10 & $100 \%$ & 92 & 0.184 & 0.184 & 0,073103125 & 0,013450975 \\
\hline $\begin{array}{l}\text { Bourreria } \\
\text { succulenta }\end{array}$ & Boraginaceae & 10 & $100 \%$ & 83 & 0.166 & 0.166 & 0,061328125 & 0,010180469 \\
\hline $\begin{array}{l}\text { Pimenta } \\
\text { racemosa }\end{array}$ & Myrtaceae & 10 & $100 \%$ & 40 & 0.08 & 0.08 & 0,10205 & 0,008164 \\
\hline $\begin{array}{l}\text { Bursera } \\
\text { simaruba }\end{array}$ & Burseraceae & 10 & $100 \%$ & 51 & 0.102 & 0.102 & 0,073103125 & 0,007456519 \\
\hline $\begin{array}{l}\text { Croton } \\
\text { corylifolius }\end{array}$ & Euphorbiaceae & 9 & $90 \%$ & 52 & 0.104 & 0,0936 & 0,0529875 & 0,00495963 \\
\hline
\end{tabular}


Absolute frequency:- presence of the species in different quadrats. / Relative frequency $=$ absolute frequency / per number of quadrats $/$ Density $=$ number of individuals / station surface / Distribution index $=$ Relative frequency $x$ Density $/$ Dominance index $=$ Distribution index $\times$ Basal surface (basal area). (*):- Species apart from the regenerations.

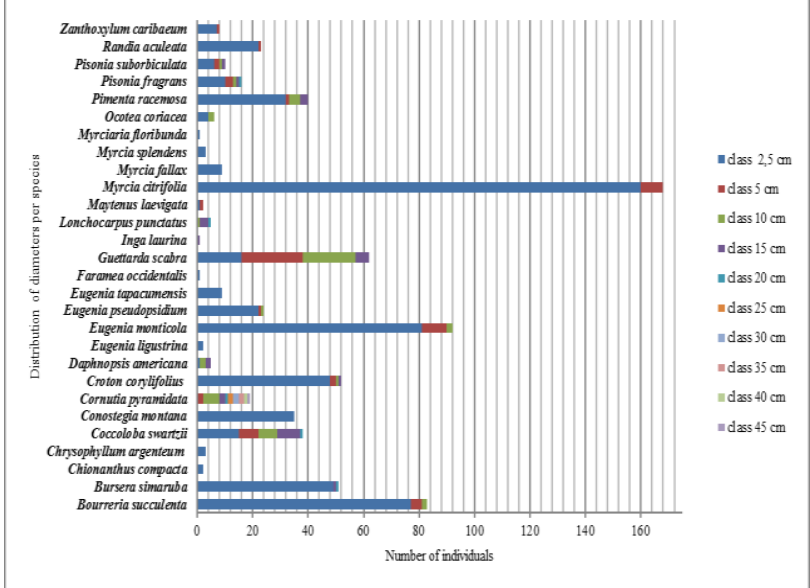

Figure 24:- - Distribution of diameters

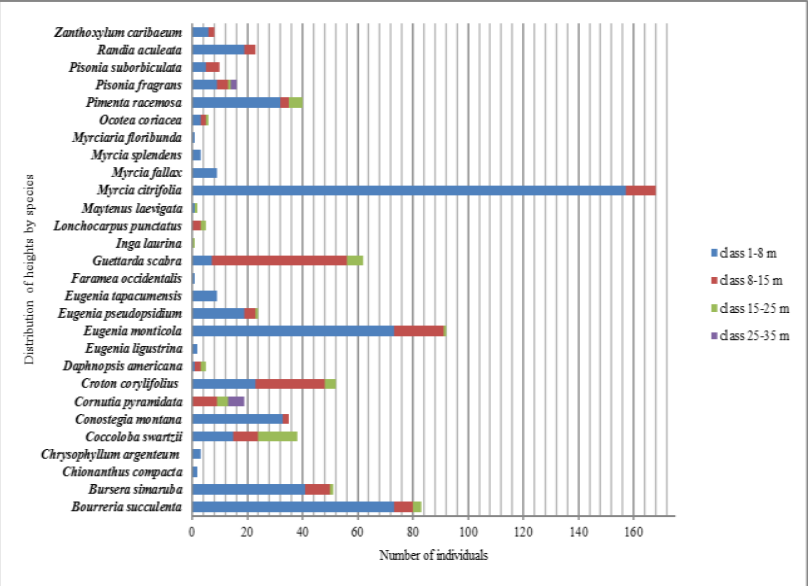

Figure 25:- - Distribution of heights

Station 12:- -Evergreen seasonal floristic unit type (mesophilic) or ombro-evergreen seasonal [(hygro-mésophile) forest $500 \mathrm{~m}^{2}$, Figure 1].

This station is characterised by specific (in this case) notable diversity, an average to high basal area for Simarouba amara, Funtumia elastica, Inga ingoides, Sapium caribaeum, Cupania americana, Myrcia splendens, Tabernaemontana citrifolia, Hirtella triandra, Andira inermis and Zanthoxylum caribaeum (Figures 26 and 27).

Table 12:- - The main ecological and structural parameters of the dominant species

\begin{tabular}{|c|c|c|c|c|c|c|c|c|}
\hline Species & Families & $\begin{array}{l}\text { Absolut } \\
\mathrm{e} \\
\text { frequenc } \\
\mathrm{y}\end{array}$ & $\begin{array}{l}\text { Relative } \\
\text { frequenc } \\
\mathrm{y}\end{array}$ & $\begin{array}{l}\text { Number } \\
\text { of } \\
\text { individua } \\
\text { ls }(*)\end{array}$ & Density & $\begin{array}{l}\text { Distributio } \\
\mathrm{n} \text { index }\end{array}$ & $\begin{array}{l}\text { Total basal } \\
\text { area by } \\
\text { species }\end{array}$ & $\begin{array}{l}\text { Dominance } \\
\text { index }\end{array}$ \\
\hline $\begin{array}{l}\text { Simarou } \\
\text { ba amara }\end{array}$ & simaroubaceae & 8 & $89 \%$ & 32 & $\begin{array}{l}0,0215488 \\
22\end{array}$ & $\begin{array}{l}0,0191545 \\
08\end{array}$ & $\begin{array}{l}2,5056218 \\
75\end{array}$ & $\begin{array}{l}0,0479939 \\
54 \\
\end{array}$ \\
\hline $\begin{array}{l}\text { Funtumi } \\
\text { a elastica }\end{array}$ & Apocynaceae & 9 & $100 \%$ & 220 & $\begin{array}{l}0,1481481 \\
48\end{array}$ & $\begin{array}{l}0,1481481 \\
48\end{array}$ & 0,255125 & $\begin{array}{l}0,0377962 \\
96\end{array}$ \\
\hline $\begin{array}{l}\text { Inga } \\
\text { ingoides }\end{array}$ & Mimosaceae & 8 & $89 \%$ & 14 & $\begin{array}{l}0,0094276 \\
09\end{array}$ & $\begin{array}{l}0,0083800 \\
97\end{array}$ & 2,4825625 & $\begin{array}{l}0,0208041 \\
15\end{array}$ \\
\hline $\begin{array}{l}\text { Sapium } \\
\text { caribaeu } \\
m\end{array}$ & Euphorbiaceae & 7 & $78 \%$ & 29 & $\begin{array}{l}0,0195286 \\
2\end{array}$ & $\begin{array}{l}0,0151889 \\
26\end{array}$ & $\begin{array}{l}0,8546687 \\
5\end{array}$ & $\begin{array}{l}0,0129815 \\
01\end{array}$ \\
\hline $\begin{array}{l}\text { Cupania } \\
\text { american } \\
a\end{array}$ & Sapindaceae & 9 & $100 \%$ & 53 & $\begin{array}{l}0,0356902 \\
36\end{array}$ & $\begin{array}{l}0,0356902 \\
36\end{array}$ & $\begin{array}{l}0,1064656 \\
25\end{array}$ & $\begin{array}{l}0,0037997 \\
83\end{array}$ \\
\hline $\begin{array}{l}\text { Myrcia } \\
\text { splenden } \\
\text { s }\end{array}$ & Myrtaceae & 9 & $100 \%$ & 79 & $\begin{array}{l}0,0531986 \\
53\end{array}$ & \begin{tabular}{|l|}
0,0531986 \\
53
\end{tabular} & $\begin{array}{l}0,0578937 \\
5\end{array}$ & $\begin{array}{l}0,0030798 \\
7\end{array}$ \\
\hline $\begin{array}{l}\text { Hirtella } \\
\text { triandra }\end{array}$ & $\begin{array}{l}\text { Chrysobalanace } \\
\text { ae }\end{array}$ & 8 & $89 \%$ & 14 & $\begin{array}{l}0,0094276 \\
09\end{array}$ & $\begin{array}{l}0,0083800 \\
97\end{array}$ & 0,2453125 & $\begin{array}{l}0,0020557 \\
43\end{array}$ \\
\hline $\begin{array}{l}\text { Andirá } \\
\text { inermis }\end{array}$ & Fabaceae & 7 & $78 \%$ & 17 & $\begin{array}{l}0,0114478 \\
11\end{array}$ & $\begin{array}{l}0,0089038 \\
53\end{array}$ & $\begin{array}{l}0,1084281 \\
25\end{array}$ & $\begin{array}{l}0,0009654 \\
28\end{array}$ \\
\hline
\end{tabular}

Absolute frequency:- presence of the species in different quadrats. / Relative frequency $=$ absolute frequency / per number of quadrats $/$ Density $=$ number of individuals / station surface / Distribution index $=$ Relative frequency $x$ 
Density $/$ Dominance index $=$ Distribution index $\times$ Basal surface (basal area). $(*)$ :- Species apart from the regenerations.

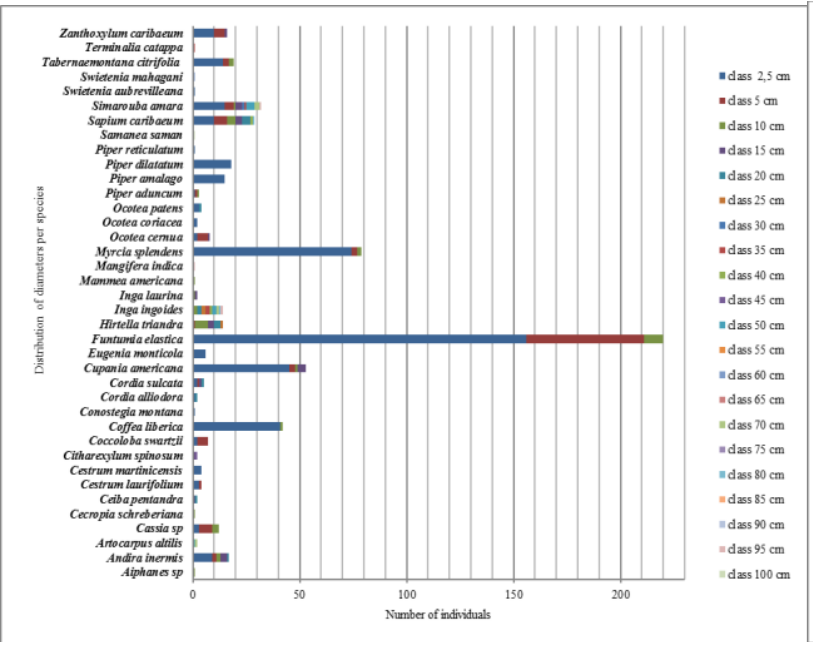

Figure 26:- - Distribution of diameters

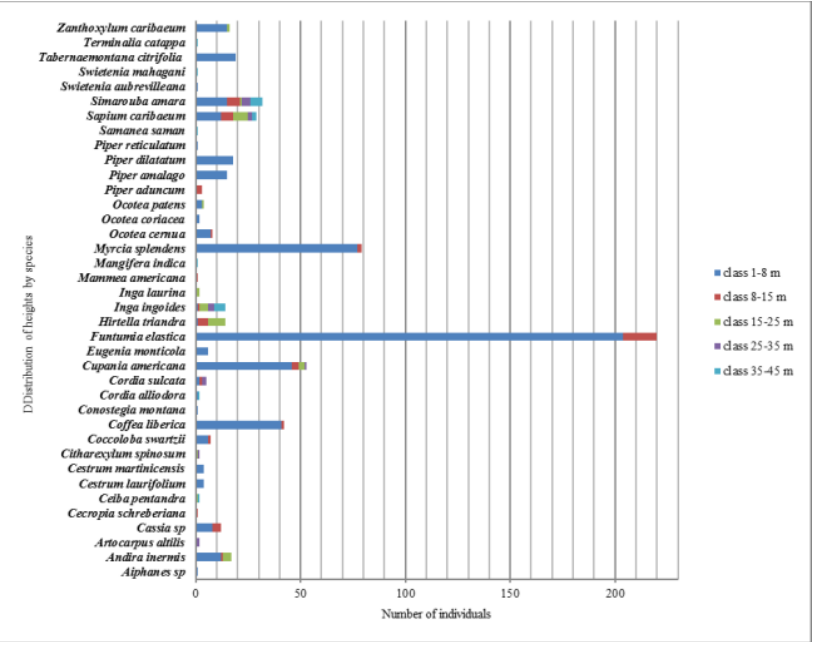

Figure 27:- - Distribution of heights

Station 13:- - Meso-hygrophile floristic unit (ombro-evergreen seasonal tropical forest:- ecotone) in the secondary structured forest stage (two defined strata however the total forest volume is occupied by trees with varying heights and ecological strategies). (920 $\mathrm{m}^{2}$, Figure 1).

Simarouba amara, Myrcia splendens and Cordia alliodora are the dominant species. This is due to their modes of height and diameter distribution (Figures 28 and 29) as well as to their means of distribution and their population basal areas. Although having low densities and low biomass, some species of the later succession stages are present either in the form of mature specimens which are relics of an earlier dynamic phase, or in the form of regenerations:Hymenaea courbaril, Cupania americana Andira inermis, Sapium caribaeum, Homalium racemosum, Hirtella triandra, Brosimum alicastrum. We also note the presence of an invasive species, Funtumia elastica, which is also well distributed in the various quadrats despite its low basal area.

Table 13:- - The main ecological and structural parameters of the dominant species

\begin{tabular}{|l|l|l|l|l|l|l|l|l|}
\hline Species & Families & $\begin{array}{l}\text { Absolute } \\
\text { frequenc } \\
\mathrm{y}\end{array}$ & $\begin{array}{l}\text { Relative } \\
\text { frequenc } \\
\mathrm{y}\end{array}$ & $\begin{array}{l}\text { Number } \\
\text { of } \\
\text { individua } \\
\text { s }(*)\end{array}$ & Density & $\begin{array}{l}\text { Distributio } \\
\mathrm{n} \text { index }\end{array}$ & $\begin{array}{l}\text { Total basal } \\
\text { area by } \\
\text { species }\end{array}$ & $\begin{array}{l}\text { Dominance } \\
\text { index }\end{array}$ \\
\hline $\begin{array}{l}\text { Simaroub } \\
\text { a amara }\end{array}$ & $\begin{array}{l}\text { Simaroubace } \\
\text { ae }\end{array}$ & 7 & $78 \%$ & 53 & $\begin{array}{l}0,05760869 \\
6\end{array}$ & $\begin{array}{l}0,04480676 \\
3\end{array}$ & $\begin{array}{l}0,75310937 \\
5\end{array}$ & $\begin{array}{l}0,03374439 \\
3\end{array}$ \\
\hline $\begin{array}{l}\text { Myrcia } \\
\text { splendens }\end{array}$ & Myrtaceae & 9 & $100 \%$ & 105 & $\begin{array}{l}0,11413043 \\
5\end{array}$ & $\begin{array}{l}0,11413043 \\
5\end{array}$ & $\begin{array}{l}0,18202187 \\
5\end{array}$ & $\begin{array}{l}0,02077423 \\
6\end{array}$ \\
\hline $\begin{array}{l}\text { Cordia } \\
\text { alliodora }\end{array}$ & Boraginaceae & 5 & $56 \%$ & 44 & $\begin{array}{l}0,04782608 \\
7\end{array}$ & $\begin{array}{l}0,02657004 \\
8\end{array}$ & $\begin{array}{l}0,4533375 \\
0\end{array}$ \\
\hline
\end{tabular}

Absolute frequency:- presence of the species in different quadrats. / Relative frequency $=$ absolute frequency / per number of quadrats / Density $=$ number of individuals / station surface / Distribution index $=$ Relative frequency $\times$ Density / Dominance index $=$ Distribution index $\times$ Basal surface (basal area). (*):- Species apart from the regenerations 


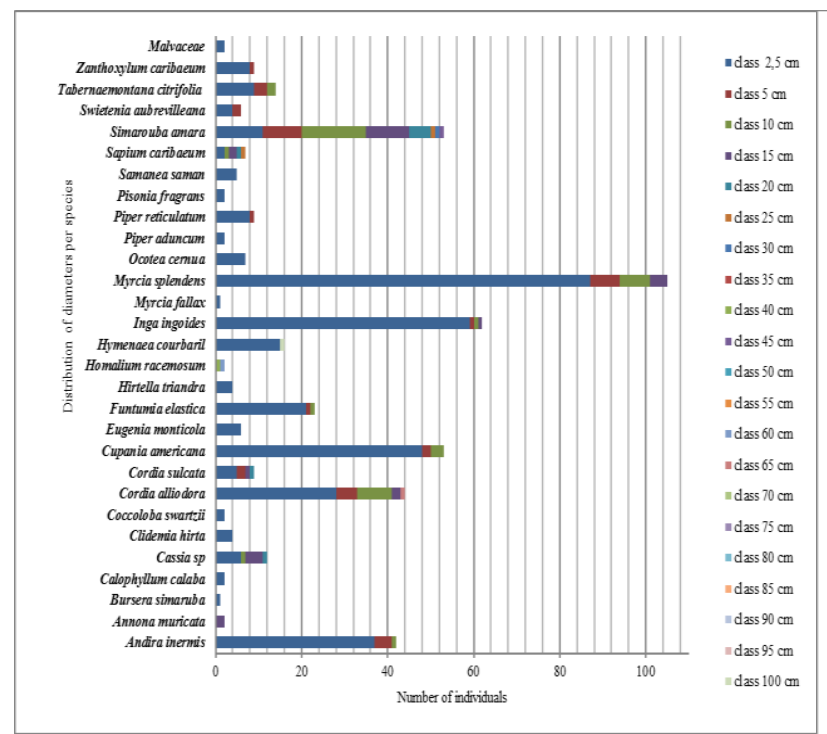

Figure 28:- - Distribution of diameters

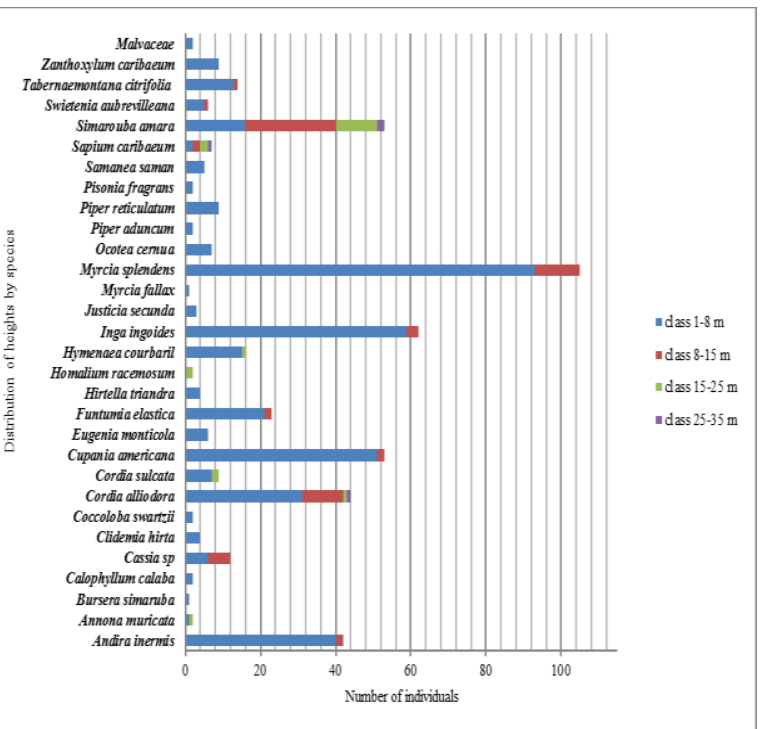

Figure 29:- - Distribution of heights

The reports of species dominance for all stations:-

8351 individuals constitute the size of the populations of all species. From a taxonomic point of view they are 153 in number and correspond to 114 genus and 56 families. For all stations, the most widely distributed species are in order of importance:- Inga ingoides, Eugenia monticola, Myrcia splendens, Simarouba amara, Pimenta racemosa, Funtumia elastica, Pisonia fragrans, Coccoloba swartzii, Calliandratergemina. Cupania americana, Ocotea coriacea and Piper amalago (Annex 1). With regard to the dominance index, there are four major species with various combinations between their distribution index and basal area:- Inga ingoides, Eugenia monticola, Myrcia splendens and Simarouba amara. They are the most competitive in relation to the environmental factors (Annex 1). Taxa whose dominance index (ID) ranges between $0.5-0.09$ are regarded as low in the ecosystem context of this station. The rest of the species (ID $<0.09$ ) are cumulated and exhibit low distribution and a very low basal area. They exhibit a low degree of concurrence but some are in their early stages of their morphogenetic evolution. Funtumia elastica and Cupania americana potentially invasive species and respectively rare species have a total average global distribution and basal area which results in relatively low indices of dominance (Annex 1).

\section{Species - survey stations:-}

Differences between stations with regard to their collections of species using CFLs (XLSTAT):-

Considering the species' bio-demographic structures per station, the CFLs (Factorial Correspondences Analysis) allowed us to differentiate between survey stations. We use only the results of axes 1 and 2 which combine the maximum of inertia in other words $38.33 \%$ (Figure 30). Axis 1 shows environmental features specific to the environments while axis 2 differentiates between levels of ecosystem evolution. Stations 1, 2, 6, 7, 8, 10, 12 \& 13 match mesophilic environments or meso-hygrophile environments in some cases where the containment is important (Figure 30). However, within stations 3, 4, 5, 9 \& 11, the eco-climatic conditions are typical for xeric environments (Figure 30). The mesophilic stations include forest groups on slopes protected from the wind (station 10) and respectively riparian terraces $(1,2,6,7,8,12 \& 13)$. Irrespective of the considered biotopes, either mesophilic or xeric, the stations are placed at different stages of plant succession (Figure 30). Stations 1, $2 \& 6$ are among the most regressive and consist of matrix shrub eco-units with some remaining mature trees with important biovolumes (only in stations $1 \& 2$ ). The stations associated with the xeric environments are colonized by phytocenoses between the shrub, pre-forest (stations $3,4 \& 5$ ) and young unstructured forest with no defined stratification (9 and 11) stages. 


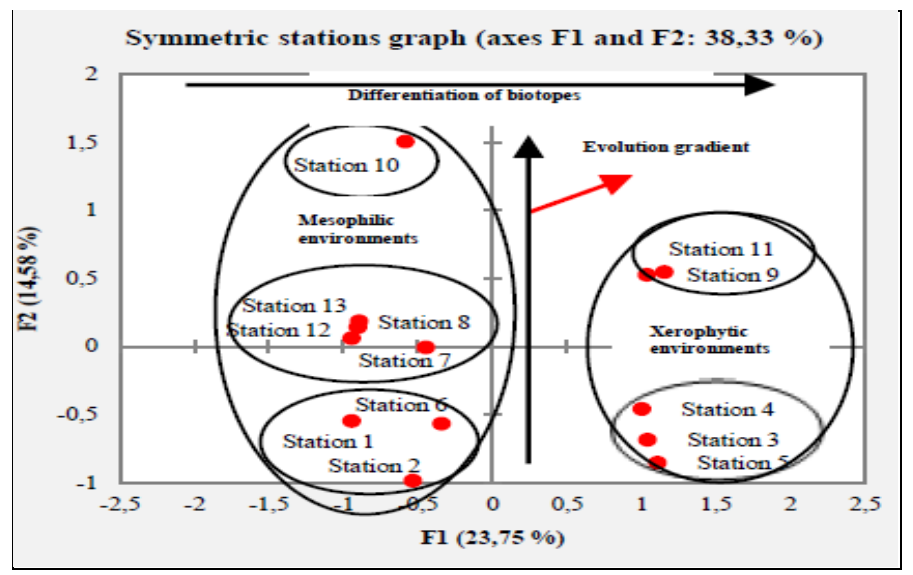

Figure 30:- Environmental and temporal differentiation between stations

Irrespective of the dominance relationship between the taxa, Figure 31 shows clear differences between wet biotope species (A, annex 2) and those of dry environments (B, annex 2). This differentiation allows us to distinctively connect different species in the secondary shrub and pre-forest stages (A3 and B2, Figure 31), or in the more advanced unstructured or barely structured forest stages (A1, A2 and B1, Figure 31). Logically, the more generalist species are strongly associated with stations 1 and 2 (riparian terraces) and stations 3, 4 and 5 (xeric coastal slopes).

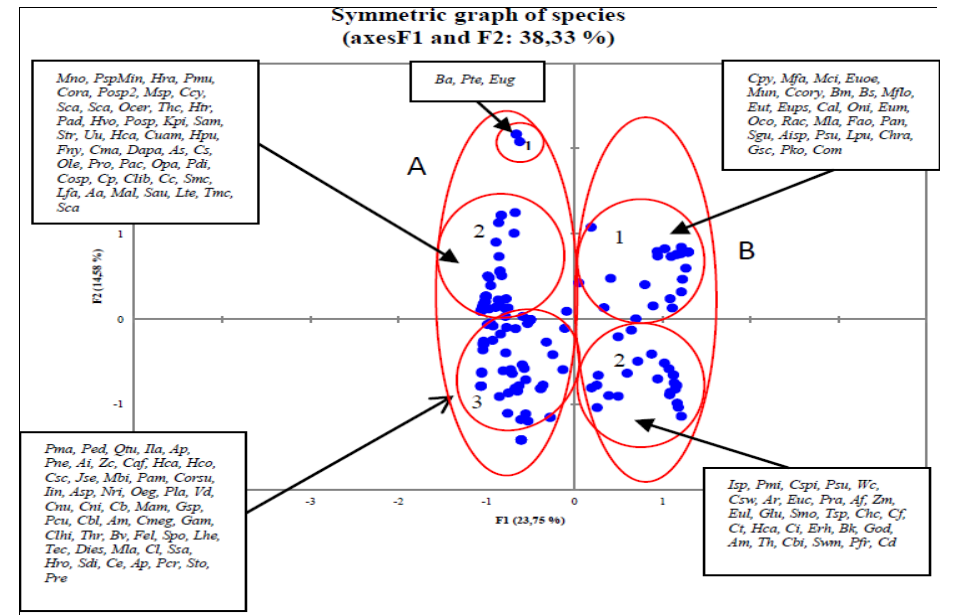

Figure 31:- Environmental and temporal Differentiation between species (annex 2)

Differentiation between stations using Clustering:-

Use of the EM (Expectation Maximization) algorithm for station characterization:-

EM assigns a probability distribution to each instance that indicates the probability of belonging to any of the classes. EM may decide the number of clusters to create by using cross-validation, or the user can specify the number of clusters to generate. For this analysis, the attributes are:- NomStation (The station name); AppBioclim (Bioclimatic class with two possible values:- xerophytic or mesophilic); FaciesTopo (Topographic features of the station with two possibilities:- riparian terrace or slope); Anthropization (allows us to estimate the anthropization degree of the stations:- PA (little Anthropized, MA:- moderately Anthropized, TA:- very Anthropized);) StadeEvolution (allows us to specify the evolution level of plant formation of the relevant station:- FJAPS (young barely structured forest), FPS - FJ (Pre-forest to young forest formation), AM (Mature Tree formation), FS (Secondary Forest), FC (Composite formation:- shrub, pre-forest and forest units).

The treatments performed using the EM algorithm starting from ecological descriptors of the study stations show us quite significant differences. There are differences both in topography (Figures $32 \& 34$ ), biotopes (Figures $33 \&$ 34 ), dynamic stages (Figures 32, 33 \& 35) and the degree of anthropization (the qualitative descriptor corresponds to the physiognomic type of the stations, Figure 35). There are two station groups:- S1, S2, S6, S7, S8, S10, S12 and S13 are mesophilic and S3, S4, S5, S9 and S11 are xerophytic (Figure 32). The latter as well as S10 is located on 
variable gradient slopes while others occupy portions of riparian terraces (Figure 32). With less precision, we can also differentiate between the anthropization degree of the floristic station formations and associate them with dynamic stages (Figure 35). Generally speaking, the xerophytic stations are less developed on the scale of plant succession and therefore, they are logically more anthropized.

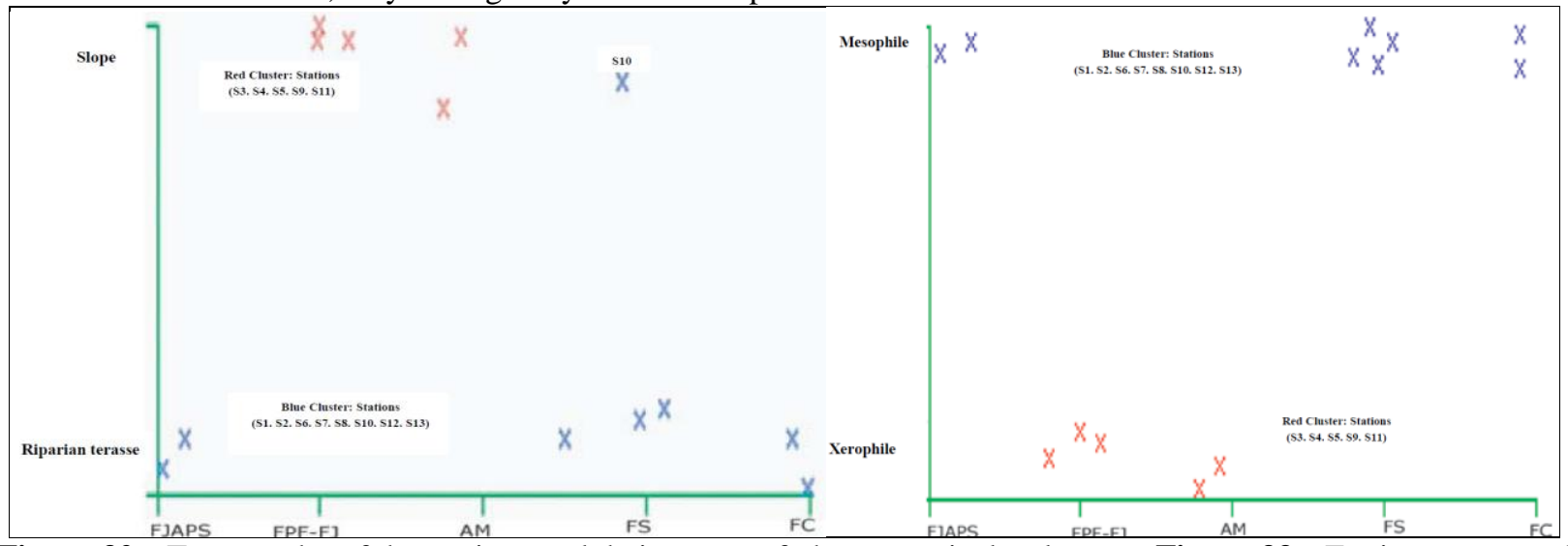

Figure 32:- Topography of the stations and their stages of phytocenosis developmentFigure 33:- Environments and evolution stages

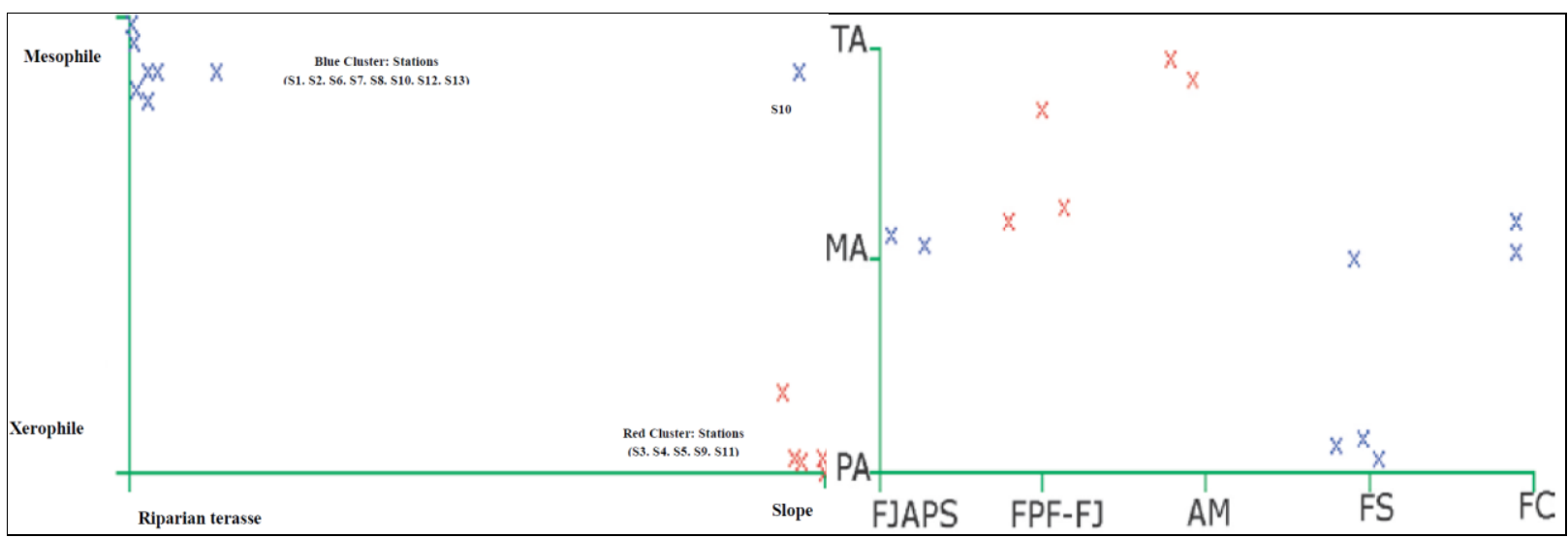

Figure 34:- Environments and topography

Figure 35:- Anthropization and evolution stages

Using the SimpleKmeans algorithm for the characterization of the species of all stations:-

The attributes by species for this analysis are the following:- Name-Species; FreqAbs (Absolute frequency); FreqRel (Relative frequency); NbreIndEsp (Number of individuals per species); Density; IDIS (Index of distribution); SurfTerriere (Basal Area); IDomi (Dominance index).

In Figure 36 the blue cluster allows us to identify the predominant species affected by a dominance index (ID) > 0.0314 , an Index of distribution (Id) > 0,01436 and a basal Surface (basal area) > 1,0572 (Annex 2). On the $\mathrm{x}$ axis we see a ratio of $10^{4}$ between the species with the largest and the lowest basal area and on the y axis a factor of $10^{4}$ between the species with the greatest and lowest Index of distribution (Annex 2, Figure 36). The species with a high index of distribution and a relatively high basal area (blue cluster) mean that the green and red clusters are little differentiated and grouped in the vicinity of the origin (Annex 1, Figure 36). Accordingly, we propose to remove these species from the analysis file as well as those with very low values close to 0 for the Index of distributionand basal area:- those are species with an Dominance index(ID) $<1.2610^{-5}$. Due to their very low biomass, the latter cause important reports on the $\mathrm{x}$ and $\mathrm{y}$ axes between the highest and lowest values:- and this occurs both for the basal area and for theIndex of distribution ${ }^{2}$.

\footnotetext{
${ }^{2}$ We mention that the Ficus nymphaeifolia with an ID $=1.2597510^{-5} \mathrm{Id}=8.210^{-6}$ and a basal area $=1.5386$ is a
} species with very low distribution which can be found in a single station. 
Having operated the above mentioned changes, we observed that the clusters can be differentiated using the index of distribution (Id) and in a less obvious way using the basal Surface (Figure 37). The green cluster represents the species with a very low index of distribution (Id) and very low Basal Surface (Figure 37). The red cluster represents the species with a distribution of index (Id) and a Basal Surface ranging from very low to low (Figure 37). Finally, in this new context apart from Sapium caribaeum and Samanea saman, the blue cluster shows a wider distribution of species with a Basal Surface ranging from low to medium (Figure 37). We propose to remove the two little distributed high basal surface species from the data file:- Sapium caribaeum and Samanea saman. We also remove the species with an Id $<10^{-5}$ :- Artocarpus altilis and Swietenia mahagoni (Annex 1).

In this last configuration, the Red Cluster (Id > 0.0085725 and Basal Surface > 0.13246875) includes moderately distributed species with a low to medium basal surface (Figure 38). The blue Cluster consists only of the following species with an ID $<0.0071233$ and a basal surface $>0.48915314$. Finally, the green cluster represents the species with low ID (Dominance index), a low index of distribution (Id) and low Basal Surface out of which two are characteristic:- Odontonema nitidum and Homalium racemosum (Annex 1). The first species is the only characterised by an Id (index of distribution) higher than that of a species of the Red cluster and an Id greater than all the species of the blue cluster. However, its Basal Surface is lower than that of all species of the blue and red clusters. Therefore we consider that this species could be included in the Red cluster but it would have the lowest Basal Surface.

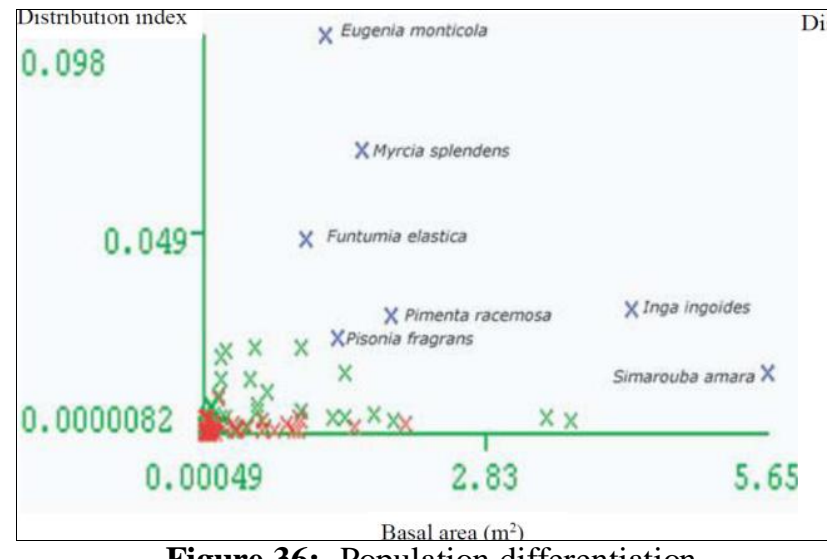

Figure 36:- Population differentiation

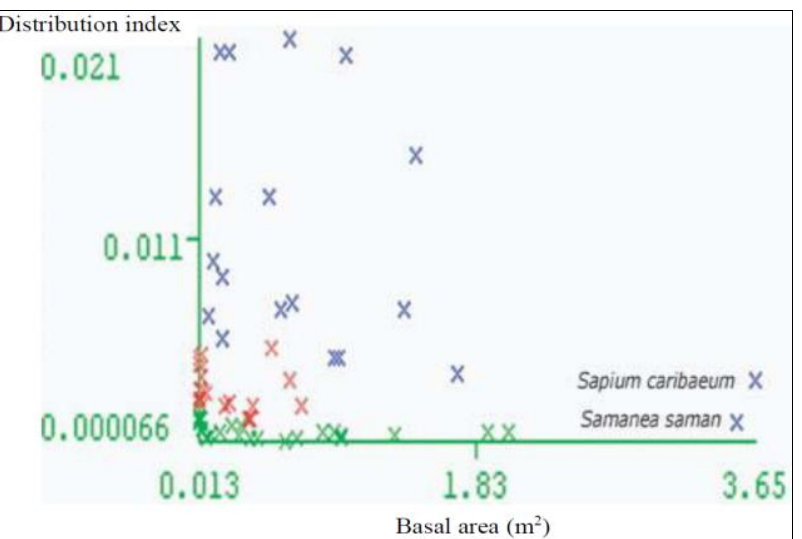

Figure 37:- Population differentiation

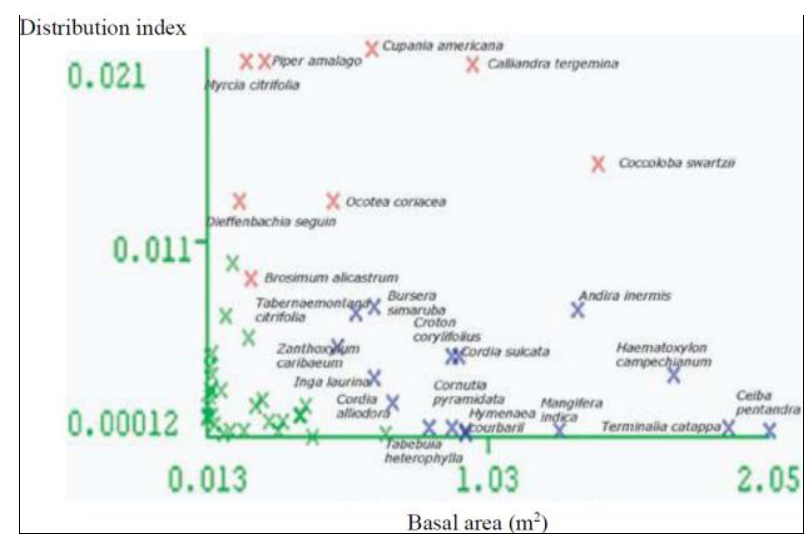

Figure 38- Population differentiation

\section{Discussion:-}

Review of the descriptive analysis of the stations:-

The structural and architectural parameters must be linked to the very particular character of the ZNIEFF vegetation in Case Navire which is composed of phytocenoses belonging to different phases of temporal evolution. These are the result of human activities differentiated by frequency and intensity. Reports regarding the site importance of species populations, the distribution of diameters and heights characterize plant groups with different ages, floristic 
compositions and physiognomies which correspond to the following dynamic stages:- mature shrub, pre-forest, young barely structured forest, secondary forest. Despite the fact that we can associate the survey stations with evolution stages the latter are often composed of a conglomerate of shrub, pre-forest and forest eco-units with variable frequency ratios. For example, the stations colonized mostly by shrub units belong to the shrub dynamic stage. The same applies for the stations consisting either in mature shrub units surpassed by some tree taxa or in forest units, which respectively can be connected to the pre-forest and forest successional stages. Everything seems to indicate that the eco-units of the surveyed formations correspond to interlocked succession stages. This phenomenon is an ecosystem response to old and new anthropization terms:- recolonization after the abandonment of vegetable crops on small intra-forest plots, the recovery of vegetation on the ruins of precarious dwellings, selective samples of species for the needs of everyday life (this form of resource utilization was and remains very significant). Ultimately the structural differences of the diameter and height histograms of the xerophytic and mesophilic stations testify to a human influence that occurred throughout many centuries ${ }^{3}$. Depending on the biotope and in the light of the Dominance index (ID), the site diversity of the dominant formations results from combinations of species linked to the structure of the biophysical factors in which Man plays a major role. In other words, the temporal dynamics of the collection of affine species distinctively characterizing the moderately wet and dry environments has been and is being guided by human activities to a degree. We can state that today's species and the phytocenoses they form are anthropophilic since the structure of their population and their dominance is under anthropogenic stress.

The clarifications brought by the statistical approaches (AFC and Clustering):-

The AFC and Clustering results fully match the above mentioned interpretations. The EM algorithm has allowed us to differentiate between stations and thus species which are endemic due to the (moderately wet or dry) environments, the stages of evolution, topographic facies and the degree of anthropization (Figures 32 , 33 34 \& 35 ). Among the statistical treatments, those derived from the SimpleKmeans algorithm are a valuable contribution to the multifactorial analysis (AFC) and the classical ecological description based on indicators such as the Basal Surface, the Index of distribution (Id) and the Dominance index (ID). In fact, this algorithm highlights the population gaps between the different species in principal with regard to their strength and their total Basal Surfaces. First, we were able to differentiate between the dominant species whose representatives have an average to high index of distribution and also an average to high basal Surface (Figure 36). These species are present in a large number of stations and occupy a fairly wide range of diameter classes. Secondly, when the previous species are removed from the file we get three new groups which are not totally disjointed due to the existence of two sparsely distributed species with a high basal Surface (Figure 37). Thirdly, after removing these species from the file data, the population differences are far more clear (Figure 38). Ultimately, the statistical analyses match the descriptions of the survey stations and allow us to better decipher the ecological strategies of species whose population structure is a relevant indicator. Within the different stations, some species are considered balanced because their individuals occupy many diameter classes:- they are often dominant (Figure 36, annex 1). Others have individuals concentrated in low diameter classes:- these are often species in regeneration or small size trees and therefore they have low aboveground biomass (Figure 36).

\section{Conclusion:-}

The ecological study of the Case Navire ZNIEFF stations highlighted the deeply heterogeneous nature of its vegetation. In reality the environmental differences are added to those caused by human activities. The diversity of species, of the phytocenoses and the floristic units that make up the survey stations result in a dense mosaic both within the stations and between them. From one formation to another and irrespective of the environment, the dominant species formations vary, the different dynamic stages affine species intermingle. This heterogeneity is also structural (distribution of diameters) and architectural (distribution of heights). Generally speaking, very few individuals have high basal areas and reach heights greater than 30 metres. Large trees can often be found in matrices of trees in full morphogenetic development or in matrices composed of mature shrubs. In reality, the ecological descriptors analysed in this study show a diversity of phytocenotic responses in connection with a variety of anthropization means taking place throughout several decades. From this point of view, this type of ecosystem context is specific to the study of vegetation dynamics.

\footnotetext{
${ }^{3}$ The French effectively took possession of the island of Martinique in 1635
} 


\section{Acknowledgements:-}

We thank the Regional Government of Martinique and the University of the West Indies respectively for their financial and administrative support.

\section{References:-}

1. Bayliss-Smith, T. et al., (2003). Rain forest composition and histories of human disturbance in Solomon Islands. AMBIO:- A Journal of the Human Environment, 32(5):- 346-352.

2. Brown, J. H. (1978). The theory of insular biogeography and the distribution of boreal birds and mammals. Great Basin Naturalist Memoirs, 209-227.

3. Burslem, D.F.R.P. et al., (2000). Short-term effects of cyclone impact and long-term recovery of tropical rain forest on Kolombangara, Solomon Islands. Journal of Ecology, 88(6):- 1063-1078.

4. Cano, E. et al., (2009). Distribution of Central American Melastomataceae:- biogeographical analysis of the Caribbean islands. Acta Botanica Gallica, 156(4):- 527-557.

5. Caujape-Castells, J. et al., (2010). Conservation of oceanic island floras:- present and future global challenges. Perspectives in Plant Ecology, Evolution and Systematics, 12(2):- 107-129.

6. Cincotta, R.P. et al. (2000). Human population in the biodiversity hotspots. Nature, 404(6781):- 990-992.

7. Cole, R.J. et al. (2010). Seed rain under tree islands planted to restore degraded lands in a tropical agricultural landscape. Ecological Applications, 20(5):- 1255-1269.

8. Denslow, J.S. et al. (2009). Invasive exotic plants in the tropical Pacific islands:- patterns of diversity. Biotropica, 41(2):- 162-170.

9. Fordham, D.A. and Brook, B.W. (2010). Why tropical island endemics are acutely susceptible to global change. Biodiversity and Conservation, 19(2):- 329-342.

10. Helmer, E.H. et al. (2008). Land cover and forest formation distributions for St. Kitts, Nevis, St. Eustatius, Grenada and Barbados from decision tree classification of cloud-cleared satellite imagery. Caribbean Journal of Science, 44(2):- 175-198.

11. Imbert, D. et al. (1996). Hurricane damage and forest structure in Guadeloupe, French West Indies. Journal of Tropical Ecology, 12(05):- 663-680.

12. Jenkins, A.P. et al. (2010). The importance of ecosystem-based management for conserving aquatic migratory pathways on tropical high islands:- a case study from Fiji. Aquatic Conservation:- Marine and Freshwater Ecosystems, 20(2), 224-238.

13. Joseph, P. (2012). The vegetation of the Lesser Antilles:- floristic diversity and ecosystemic dynamics. International Journal of Environmental Studies, 69(5):- 816-833.

14. Joseph, P. (2013). How Should the Forest Types of the Lesser Antilles be Described in the Intertropical Area. Earth Resources, 1(3):- 78-102.

15. Keitt, B. et al. (2011). The global islands invasive vertebrate eradication database:- a tool to improve and facilitate restoration of island ecosystems. Island invasives:- eradication and management. IUCN, Gland, Switzerland, 74-77.

16. Knight, D.H. (1975). A phytosociological analysis of species-rich tropical forest on Barro Colorado Island, Panama. Ecological Monographs, 259-284.

17. Leigh Jr, E.G., et al. (1993). The decline of tree diversity on newly isolated tropical islands:- a test of a null hypothesis and some implications. Evolutionary Ecology, 7(1):- 76-102.

18. Loope, L.L. and Giambelluca, T.W. (1998). Vulnerability of island tropical montane cloud forests to climate change, with special reference to East Maui, Hawaii. Climatic Change, 39(2-3):- 503-517.

19. Losos, J.B. and Ricklefs, R.E. (2009). Adaptation and diversification on islands. Nature, 457(7231):- 830-836.

20. Meyer, J.Y. and Lavergne, C. (2004). Beautés fatales:- Acanthaceae species as invasive alien plants on tropical Indo-Pacific Islands. Diversity and Distributions, 10(5-6):- 333-347.

21. Mittermeier, R.A., et al. (1998). Biodiversity hotspots and major tropical wilderness areas:- approaches to setting conservation priorities. Conservation biology, 12(3):- 516-520.

22. Morrison, L.W. (2010). Long-term non-equilibrium dynamics of insular floras:- a 17-year record. Global Ecology and Biogeography, 19(5):- 663-672.

23. Mueller-Dombois, D. and Fosberg, F.R. (2013). Vegetation of the tropical Pacific islands. Springer Science \& Business Media.

24. Myers, N. et al. (2000). Biodiversity hotspots for conservation priorities. Nature, 403(6772):- 853-858.

25. O'Dowd, D. J. et al. (2003). Invasional 'meltdown'on an oceanic island. Ecology Letters, 6(9):- 812-817. 
26. Powell, K.I. et al. (2011). A synthesis of plant invasion effects on biodiversity across spatial scales. American Journal of Botany, 98(3):- 539-548.

27. Rasingam, L. and Parthasarathy, N. (2009). Diversity of understory plants in undisturbed and disturbed tropical lowland forests of Little Andaman Island, India. Biodiversity and conservation, 18(4):- 1045-1065.

28. Reilly, A.E. (1991). The effects of Hurricane Hugo in three tropical forests in the US Virgin Islands. Biotropica, 414-419.

29. Rispoli, G. (2014). Between'Biosphere'and'Gaia'. Earth as a Living Organism in Soviet Geo-Ecology. Cosmos and History:- The Journal of Natural and Social Philosophy, 10(2):- 78-91.

30. Rizali, A. et al. (2010). Ant communities on small tropical islands:- effects of island size and isolation are obscured by habitat disturbance and 'tramp'ant species. Journal of Biogeography, 37(2):- 229-236.

31. Ruiz, J., et al. (2005). Vegetation Structure, Composition, and Species Richness Across a 56-year Chronosequence of Dry Tropical Forest on Providencia Island, Colombia1. Biotropica, 37(4):- 520-530.

32. Samways, M.J., et al. (2010). Restoration of a tropical island:- Cousine Island, Seychelles. Biodiversity and conservation, 19(2):- 425-434.

33. Santiago-Valentin, E. and Olmstead, R. G. (2004). Historical biogeography of Caribbean plants:introduction to current knowledge and possibilities from a phylogenetic perspective. Taxon, 299-319.

34. Schnitzler, A. et al. (2012). Post-Hurricane responses of climbers in a tropical mountain rain forest of Martinique. Folia Geobotanica, 47(3):- 277-291.

35. Stohlgren, T.J., et al. (1999). Exotic plant species invade hot spots of native plant diversity. Ecological monographs, 69(1):- 25-46.

36. Whittaker, R.J. et al. (2010). A general dynamic theory of oceanic island biogeography:- extending the MacArthur-Wilson theory to accommodate the rise and fall of volcanic islands. The theory of island biogeography revisited, 88-115.

Annex 1:- Ecological and structural descriptors for all the survey stations

\begin{tabular}{|c|c|c|c|c|c|c|c|}
\hline Species & $\begin{array}{l}\text { Absolute } \\
\text { frequency }\end{array}$ & $\begin{array}{l}\text { Relative } \\
\text { frequency }\end{array}$ & $\begin{array}{l}\text { Number of individuals per } \\
\text { species outside regenerations }\end{array}$ & $\begin{array}{l}\text { Densit } \\
\mathrm{y}\end{array}$ & $\begin{array}{l}\text { Distribut } \\
\text { ion index } \\
\end{array}$ & \begin{tabular}{|lr}
$\begin{array}{l}\text { Total } \\
\text { area }\end{array}$ & basal \\
species & by \\
\end{tabular} & \begin{tabular}{|l} 
Domina \\
nce \\
index
\end{tabular} \\
\hline Inga ingoides & 11 & 0,8462 & 334 & \begin{tabular}{|l|}
0,035 \\
55082 \\
5 \\
\end{tabular} & \begin{tabular}{|l|}
0,030081 \\
467 \\
\end{tabular} & 4,302781265 & $\begin{array}{l}0,12943 \\
3974 \\
\end{array}$ \\
\hline $\begin{array}{l}\text { Eugenia } \\
\text { monticola }\end{array}$ & 13 & 1.0000 & 920 & \begin{tabular}{|l|}
0,097 \\
92442 \\
8 \\
\end{tabular} & $\begin{array}{l}0,097924 \\
428\end{array}$ & 1,197125 & $\begin{array}{l}0,11722 \\
7781\end{array}$ \\
\hline $\begin{array}{l}\text { Myrcia } \\
\text { splendens }\end{array}$ & 11 & 0,8462 & 777 & $\begin{array}{l}0,082 \\
70356 \\
6\end{array}$ & $\begin{array}{l}0,069979 \\
94\end{array}$ & 1,561384635 & $\begin{array}{l}0,10926 \\
5603\end{array}$ \\
\hline $\begin{array}{l}\text { Simarouba } \\
\text { amara }\end{array}$ & 9 & 0,6923 & 195 & \begin{tabular}{|l|}
0,020 \\
75572 \\
1
\end{tabular} & $\begin{array}{l}0,014369 \\
345\end{array}$ & 5,65101876 & $\begin{array}{l}0,08120 \\
144\end{array}$ \\
\hline $\begin{array}{l}\text { Pimenta } \\
\text { racemosa }\end{array}$ & 12 & 0,9231 & 311 & \begin{tabular}{|l|}
0,033 \\
10271 \\
4
\end{tabular} & $\begin{array}{l}0,030556 \\
352\end{array}$ & 1,918391573 & $\begin{array}{l}0,05861 \\
9047\end{array}$ \\
\hline $\begin{array}{l}\text { Funtumia } \\
\text { elastica }\end{array}$ & 8 & 0,6154 & 716 & $\begin{array}{l}0,076 \\
21075\end{array}$ & $\begin{array}{l}0,046898 \\
923\end{array}$ & 1,057296895 & $\begin{array}{l}0,04958 \\
6086\end{array}$ \\
\hline $\begin{array}{l}\text { Pisonia } \\
\text { fragrans }\end{array}$ & 13 & 1.0000 & 224 & \begin{tabular}{|l|}
0,023 \\
84246 \\
9
\end{tabular} & $\begin{array}{l}0,023842 \\
469\end{array}$ & 1,31830938 & $\begin{array}{l}0,03143 \\
1751\end{array}$ \\
\hline $\begin{array}{l}\text { Coccoloba } \\
\text { swartzii }\end{array}$ & 12 & 0,9231 & 151 & $\begin{array}{l}0,016 \\
07237 \\
9\end{array}$ & $\begin{array}{l}0,014836 \\
042\end{array}$ & 1,431643765 & $\begin{array}{l}0,02123 \\
9927\end{array}$ \\
\hline $\begin{array}{l}\text { Calliandra } \\
\text { Mussa }\end{array}$ & 5 & 0,3846 & 493 & \begin{tabular}{|l|}
0,052 \\
47472 \\
1
\end{tabular} & $\begin{array}{l}0,020182 \\
585\end{array}$ & 0,9802688 & $\begin{array}{l}0,01978 \\
4358\end{array}$ \\
\hline Cupania & 10 & 0,7692 & 257 & 0,027 & 0,021042 & 0,610796573 & 0,01285 \\
\hline
\end{tabular}




\begin{tabular}{|c|c|c|c|c|c|c|c|}
\hline americana & & & & \begin{tabular}{|l|}
35497 \\
6
\end{tabular} & 289 & & 2558 \\
\hline $\begin{array}{l}\text { Sapium } \\
\text { caribaeum }\end{array}$ & 5 & 0,3846 & 76 & \begin{tabular}{|l|}
0,008 \\
08940 \\
9 \\
\end{tabular} & $\begin{array}{l}0,003111 \\
311\end{array}$ & 3,65409375 & $\begin{array}{l}0,01136 \\
9023\end{array}$ \\
\hline $\begin{array}{l}\text { Andirá } \\
\text { inermis }\end{array}$ & 7 & 0,5385 & 120 & \begin{tabular}{|l|}
0,012 \\
77275 \\
1 \\
\end{tabular} & $\begin{array}{l}0,006877 \\
635\end{array}$ & 1,36050314 & $\begin{array}{l}0,00935 \\
7045 \\
\end{array}$ \\
\hline $\begin{array}{l}\text { Ocotea } \\
\text { coriacea }\end{array}$ & 7 & 0,5385 & 222 & $\begin{array}{l}0,023 \\
62959\end{array}$ & $\begin{array}{l}0,012723 \\
625\end{array}$ & 0,47443438 & $\begin{array}{l}0,00603 \\
6525\end{array}$ \\
\hline $\begin{array}{l}\text { Haematoxylon } \\
\text { campechianu } \\
m\end{array}$ & 6 & 0,4615 & 70 & \begin{tabular}{|l|}
0,007 \\
45077 \\
2
\end{tabular} & $\begin{array}{l}0,003438 \\
818\end{array}$ & 1,71277188 & $\begin{array}{l}0,00588 \\
991\end{array}$ \\
\hline $\begin{array}{l}\text { Piper } \\
\text { amalago }\end{array}$ & 7 & 0,5385 & 353 & \begin{tabular}{|l|}
0,037 \\
57317 \\
7 \\
\end{tabular} & $\begin{array}{l}0,020231 \\
711\end{array}$ & 0,220781255 & $\begin{array}{l}0,00446 \\
6783\end{array}$ \\
\hline $\begin{array}{l}\text { Bursera } \\
\text { simaruba }\end{array}$ & 10 & 0,7692 & 87 & \begin{tabular}{|l|}
0,009 \\
26024 \\
5 \\
\end{tabular} & $\begin{array}{l}0,007123 \\
265\end{array}$ & 0,62505627 & $\begin{array}{l}0,00445 \\
2442\end{array}$ \\
\hline $\begin{array}{l}\text { Cordia } \\
\text { sulcata }\end{array}$ & 9 & 0,6923 & 59 & \begin{tabular}{|l|}
0,006 \\
27993 \\
6 \\
\end{tabular} & $\begin{array}{l}0,004347 \\
648\end{array}$ & 0,933168755 & $\begin{array}{l}0,00405 \\
7089\end{array}$ \\
\hline $\begin{array}{l}\text { Croton } \\
\text { corylifolius }\end{array}$ & 4 & 0,3077 & 133 & \begin{tabular}{|l|}
0,014 \\
15646 \\
6
\end{tabular} & $\begin{array}{l}0,004355 \\
836\end{array}$ & 0,90422189 & $\begin{array}{l}0,00393 \\
8642\end{array}$ \\
\hline $\begin{array}{l}\text { Tabernaemont } \\
\text { ana citrifolia }\end{array}$ & 8 & 0,6154 & 104 & \begin{tabular}{|l|}
0,011 \\
06971 \\
8 \\
\end{tabular} & $\begin{array}{l}0,006812 \\
134\end{array}$ & 0,55823126 & $\begin{array}{l}0,00380 \\
2746 \\
\end{array}$ \\
\hline $\begin{array}{l}\text { Samanea } \\
\text { saman }\end{array}$ & 6 & 0,4615 & 19 & $\begin{array}{l}0,002 \\
02235 \\
2\end{array}$ & $\begin{array}{l}0,000933 \\
393\end{array}$ & 3,534953125 & $\begin{array}{l}0,00329 \\
9502\end{array}$ \\
\hline $\begin{array}{l}\text { Myrcia } \\
\text { citrifolia }\end{array}$ & 9 & 0,6923 & 276 & \begin{tabular}{|l|}
0,029 \\
37732 \\
8
\end{tabular} & $\begin{array}{l}0,020338 \\
15\end{array}$ & 0,158962505 & $\begin{array}{l}0,00323 \\
3003\end{array}$ \\
\hline $\begin{array}{l}\text { Zanthoxylum } \\
\text { caribaeum }\end{array}$ & 10 & 0,7692 & 60 & $\begin{array}{l}0,006 \\
38637 \\
6\end{array}$ & $\begin{array}{l}0,004912 \\
597\end{array}$ & 0,48915314 & $\begin{array}{l}0,00240 \\
3012\end{array}$ \\
\hline Inga laurina & 11 & 0,8462 & 36 & \begin{tabular}{|l|}
0,003 \\
83182 \\
5
\end{tabular} & $\begin{array}{l}0,003242 \\
314\end{array}$ & 0,621621875 & $\begin{array}{l}0,00201 \\
5493\end{array}$ \\
\hline $\begin{array}{l}\text { Dieffenbachia } \\
\text { seguine }\end{array}$ & 7 & 0,5385 & 223 & \begin{tabular}{|l|}
0,023 \\
73603 \\
\end{tabular} & $\begin{array}{l}0,012780 \\
939\end{array}$ & 0,13246875 & $\begin{array}{l}0,00169 \\
3075\end{array}$ \\
\hline $\begin{array}{l}\text { Brosimum } \\
\text { alicastrum }\end{array}$ & 3 & 0,2308 & 349 & $\begin{array}{l}0,037 \\
14741 \\
9\end{array}$ & $\begin{array}{l}0,008572 \\
481\end{array}$ & 0,171228125 & $\begin{array}{l}0,00146 \\
785\end{array}$ \\
\hline $\begin{array}{l}\text { Cordia } \\
\text { alliodora }\end{array}$ & 4 & 0,3077 & 55 & \begin{tabular}{|l|}
0,005 \\
85417 \\
8 \\
\end{tabular} & $\begin{array}{l}0,001801 \\
285\end{array}$ & 0,68834688 & $\begin{array}{l}0,00123 \\
9909\end{array}$ \\
\hline $\begin{array}{l}\text { Odontonema } \\
\text { nitidum }\end{array}$ & 5 & 0,3846 & 228 & \begin{tabular}{|l|}
0,024 \\
26822 \\
8
\end{tabular} & $\begin{array}{l}0,009333 \\
934\end{array}$ & 0,1118625 & $\begin{array}{l}0,00104 \\
4117\end{array}$ \\
\hline $\begin{array}{l}\text { Terminalia } \\
\text { catappa }\end{array}$ & 5 & 0,3846 & 12 & \begin{tabular}{|l|}
0,001 \\
27727 \\
5
\end{tabular} & $\begin{array}{l}0,000491 \\
26\end{array}$ & 1,90865313 & $\begin{array}{l}0,00093 \\
7644\end{array}$ \\
\hline Bourreria & 6 & 0,4615 & 109 & 0,011 & 0,005354 & 0,17024689 & 0,00091 \\
\hline
\end{tabular}




\begin{tabular}{|c|c|c|c|c|c|c|c|}
\hline succulenta & & & & \begin{tabular}{|l|}
60191 \\
6 \\
\end{tabular} & 73 & & 1626 \\
\hline $\begin{array}{l}\text { Ceiba } \\
\text { pentandra }\end{array}$ & 4 & 0,3077 & 13 & \begin{tabular}{|l|}
0,001 \\
38371 \\
5
\end{tabular} & $\begin{array}{l}0,000425 \\
758\end{array}$ & 2,05375625 & $\begin{array}{l}0,00087 \\
4404\end{array}$ \\
\hline $\begin{array}{l}\text { Citharexylum } \\
\text { spinosum }\end{array}$ & 7 & 0,5385 & 31 & $\begin{array}{l}0,003 \\
29962 \\
7\end{array}$ & $\begin{array}{l}0,001776 \\
722\end{array}$ & 0,373856635 & $\begin{array}{l}0,00066 \\
4239\end{array}$ \\
\hline $\begin{array}{l}\text { Piper } \\
\text { reticulatum }\end{array}$ & 6 & 0,4615 & 133 & \begin{tabular}{|l|}
0,014 \\
15646 \\
6
\end{tabular} & $\begin{array}{l}0,006533 \\
754\end{array}$ & 0,08144376 & $\begin{array}{l}0,00053 \\
2133\end{array}$ \\
\hline $\begin{array}{l}\text { Cornutia } \\
\text { pyramidata }\end{array}$ & 3 & 0,2308 & 23 & \begin{tabular}{|l|}
0,002 \\
44811 \\
1
\end{tabular} & $\begin{array}{l}0,000564 \\
949\end{array}$ & 0,90275 & $\begin{array}{l}0,00051 \\
0007\end{array}$ \\
\hline $\begin{array}{l}\text { Guettarda } \\
\text { odorata }\end{array}$ & 3 & 0,2308 & 50 & \begin{tabular}{|l|}
0,005 \\
32198 \\
\end{tabular} & $\begin{array}{l}0,001228 \\
149\end{array}$ & 0,35570313 & $\begin{array}{l}0,00043 \\
6857\end{array}$ \\
\hline $\begin{array}{l}\text { Chrysophyllu } \\
\text { m argenteum }\end{array}$ & 8 & 0,6154 & 30 & \begin{tabular}{|l|}
0,003 \\
19318 \\
8 \\
\end{tabular} & $\begin{array}{l}0,001965 \\
039\end{array}$ & 0,219800015 & $\begin{array}{l}0,00043 \\
1916\end{array}$ \\
\hline $\begin{array}{l}\text { Guettarda } \\
\text { scabra }\end{array}$ & 2 & 0,1538 & 75 & \begin{tabular}{|l|}
0,007 \\
98297 \\
\end{tabular} & \begin{tabular}{|l}
0,001228 \\
149 \\
\end{tabular} & 0,34687188 & $\begin{array}{l}0,00042 \\
601 \\
\end{array}$ \\
\hline $\begin{array}{l}\text { Tabebuia } \\
\text { heterophylla }\end{array}$ & 3 & 0,2308 & 20 & \begin{tabular}{|l|}
0,002 \\
12879 \\
2
\end{tabular} & $\begin{array}{l}0,000491 \\
26\end{array}$ & 0,8222875 & $\begin{array}{l}0,00040 \\
3957\end{array}$ \\
\hline $\begin{array}{l}\text { Mangifera } \\
\text { indica }\end{array}$ & 6 & 0,4615 & 6 & \begin{tabular}{|l|}
0,000 \\
63863 \\
8
\end{tabular} & $\begin{array}{l}0,000294 \\
756\end{array}$ & 1,29623125 & $\begin{array}{l}0,00038 \\
2072\end{array}$ \\
\hline $\begin{array}{l}\text { Amphilophium } \\
\text { paniculatum }\end{array}$ & 7 & 0,5385 & 31 & \begin{tabular}{|l|}
0,003 \\
29962 \\
7
\end{tabular} & $\begin{array}{l}0,001776 \\
722\end{array}$ & 0,19477814 & $\begin{array}{l}0,00034 \\
6067\end{array}$ \\
\hline $\begin{array}{l}\text { Hymenaea } \\
\text { courbaril }\end{array}$ & 2 & 0,1538 & 20 & $\begin{array}{l}0,002 \\
12879 \\
2\end{array}$ & $\begin{array}{l}0,000327 \\
506\end{array}$ & 0,953284375 & $\begin{array}{l}0,00031 \\
2207\end{array}$ \\
\hline $\begin{array}{l}\text { Cecropia } \\
\text { schreberiana }\end{array}$ & 6 & 0,4615 & 18 & \begin{tabular}{|l|}
0,001 \\
91591 \\
3
\end{tabular} & $\begin{array}{l}0,000884 \\
267\end{array}$ & 0,28946936 & $\begin{array}{l}0,00025 \\
5968\end{array}$ \\
\hline $\begin{array}{l}\text { Lonchocarpus } \\
\text { punctatus }\end{array}$ & 2 & 0,1538 & 14 & \begin{tabular}{|l|}
0,001 \\
49015 \\
4
\end{tabular} & $\begin{array}{l}0,000229 \\
255\end{array}$ & 0,9518125 & $\begin{array}{l}0,00021 \\
8207\end{array}$ \\
\hline $\begin{array}{l}\text { Daphnopsis } \\
\text { americana }\end{array}$ & 6 & 0,4615 & 18 & \begin{tabular}{|l|}
0,001 \\
91591 \\
3
\end{tabular} & $\begin{array}{l}0,000884 \\
267\end{array}$ & 0,23991563 & $\begin{array}{l}0,00021 \\
215\end{array}$ \\
\hline $\begin{array}{l}\text { Chionanthus } \\
\text { compacta }\end{array}$ & 8 & 0,6154 & 39 & \begin{tabular}{|l}
0,004 \\
15114 \\
4
\end{tabular} & $\begin{array}{l}0,002554 \\
55\end{array}$ & 0,068687505 & $\begin{array}{l}0,00017 \\
5466\end{array}$ \\
\hline $\begin{array}{l}\text { Petrea } \\
\text { kohautiana }\end{array}$ & 8 & 0,6154 & 69 & $\begin{array}{l}0,007 \\
34433 \\
2\end{array}$ & $\begin{array}{l}0,004519 \\
589\end{array}$ & 0,033853125 & $\begin{array}{l}0,00015 \\
3002\end{array}$ \\
\hline $\begin{array}{l}\text { Psychotria } \\
\text { microdon }\end{array}$ & 10 & 0,7692 & 53 & \begin{tabular}{|l}
0,005 \\
64129 \\
9
\end{tabular} & $\begin{array}{l}0,004339 \\
46\end{array}$ & 0,027475 & $\begin{array}{l}0,00011 \\
9227\end{array}$ \\
\hline $\begin{array}{l}\text { Homalium } \\
\text { racemosum }\end{array}$ & 3 & 0,2308 & 7 & \begin{tabular}{|l|}
0,000 \\
74507 \\
7
\end{tabular} & $\begin{array}{l}0,000171 \\
941\end{array}$ & 0,661853125 & $\begin{array}{l}0,00011 \\
38\end{array}$ \\
\hline Erythroxylon & 11 & 0,8462 & 44 & 0,004 & 0,003962 & 0,027475 & 0,00010 \\
\hline
\end{tabular}




\begin{tabular}{|c|c|c|c|c|c|c|c|}
\hline havanense & & & & \begin{tabular}{|l|}
68334 \\
2
\end{tabular} & 828 & & 8879 \\
\hline $\begin{array}{l}\text { Randia } \\
\text { aculeata }\end{array}$ & 8 & 0,6154 & 52 & $\begin{array}{l}0,005 \\
53485 \\
9\end{array}$ & $\begin{array}{l}0,003406 \\
067\end{array}$ & 0,029928125 & $\begin{array}{l}0,00010 \\
1937\end{array}$ \\
\hline $\begin{array}{l}\text { Psychotria } \\
\text { mapourioides }\end{array}$ & 5 & 0,3846 & 61 & \begin{tabular}{|l|}
0,006 \\
49281 \\
5 \\
\end{tabular} & \begin{tabular}{|l}
0,002497 \\
237 \\
\end{tabular} & 0,03434375 & $\begin{array}{l}8,57645 \\
\text { E-05 }\end{array}$ \\
\hline $\begin{array}{l}\text { Hirtella } \\
\text { triandra }\end{array}$ & 2 & 0,1538 & 18 & \begin{tabular}{|l|}
0,001 \\
91591 \\
3 \\
\end{tabular} & $\begin{array}{l}0,000294 \\
756 \\
\end{array}$ & 0,273278125 & \begin{tabular}{|l|}
8, \\
$05503 \mathrm{E}-$ \\
05 \\
\end{tabular} \\
\hline $\begin{array}{l}\text { Piper } \\
\text { dilatatum }\end{array}$ & 6 & 0,4615 & 53 & \begin{tabular}{|l|}
0,005 \\
64129 \\
9 \\
\end{tabular} & $\begin{array}{l}0,002603 \\
676\end{array}$ & 0,026003125 & \begin{tabular}{|l}
6, \\
$77037 \mathrm{E}-$ \\
05
\end{tabular} \\
\hline Cassia SP. & 2 & 0,1538 & 25 & $\begin{array}{l}0,002 \\
66099\end{array}$ & $\begin{array}{l}0,000409 \\
383\end{array}$ & 0,15013125 & $\begin{array}{l}\text { 6,14612 } \\
\text { E-05 }\end{array}$ \\
\hline $\begin{array}{l}\text { Conostegia } \\
\text { montana }\end{array}$ & 6 & 0,4615 & 44 & \begin{tabular}{|l|}
0,004 \\
68334 \\
2 \\
\end{tabular} & $\begin{array}{l}0,002161 \\
543 \\
\end{array}$ & 0,023059375 & $\begin{array}{l}4,98438 \\
\text { E-05 }\end{array}$ \\
\hline $\begin{array}{l}\text { Vitex } \\
\text { divaricata }\end{array}$ & 3 & 0,2308 & 5 & \begin{tabular}{|l|}
0,000 \\
53219 \\
8 \\
\end{tabular} & $\begin{array}{l}0,000122 \\
815\end{array}$ & 0,39544375 & \begin{tabular}{|l}
4, \\
$85664 \mathrm{E}-$ \\
05
\end{tabular} \\
\hline Ocotea cernua & 6 & 0,4615 & 24 & \begin{tabular}{|l|}
0,002 \\
55455 \\
\end{tabular} & $\begin{array}{l}0,001179 \\
023 \\
\end{array}$ & 0,03630625 & \begin{tabular}{|l|}
4,28059 \\
E-05 \\
\end{tabular} \\
\hline $\begin{array}{l}\text { Artocarpus } \\
\text { altilis }\end{array}$ & 2 & 0,1538 & 4 & \begin{tabular}{|l|}
0,000 \\
42575 \\
8 \\
\end{tabular} & $\begin{array}{l}6,55013 \\
\text { E-05 }\end{array}$ & 0,58335313 & $\begin{array}{l}3,82104 \\
\text { E-05 }\end{array}$ \\
\hline $\begin{array}{l}\text { Mammea } \\
\text { americana }\end{array}$ & 4 & 0,3077 & 10 & \begin{tabular}{|l|}
0,001 \\
06439 \\
6 \\
\end{tabular} & $\begin{array}{l}0,000327 \\
506\end{array}$ & 0,099596875 & $\begin{array}{l}3,26186 \\
\text { E-05 }\end{array}$ \\
\hline $\begin{array}{l}\text { Chiococca } \\
\text { alba }\end{array}$ & 6 & 0,4615 & 34 & \begin{tabular}{|l|}
0,003 \\
61894 \\
6 \\
\end{tabular} & $\begin{array}{l}0,001670 \\
283\end{array}$ & 0,01668125 & $\begin{array}{l}2,78624 \\
\text { E-05 }\end{array}$ \\
\hline $\begin{array}{l}\text { Capparis } \\
\text { indica }\end{array}$ & 5 & 0,3846 & 16 & \begin{tabular}{|l|}
0,001 \\
70303 \\
4 \\
\end{tabular} & $\begin{array}{l}0,000655 \\
013 \\
\end{array}$ & 0,042194055 & $\begin{array}{l}2,76377 \\
\text { E-05 }\end{array}$ \\
\hline $\begin{array}{l}\text { Swietenia } \\
\text { mahagoni }\end{array}$ & 3 & 0,2308 & 3 & $\begin{array}{l}0,000 \\
31931 \\
9\end{array}$ & $\begin{array}{l}\text { 7,3689T } \\
\text { H-05 }\end{array}$ & 0,349325 & $\begin{array}{l}2,57414 \\
\text { E-05 }\end{array}$ \\
\hline $\begin{array}{l}\text { Capparis } \\
\text { baducca }\end{array}$ & 5 & 0,3846 & 26 & \begin{tabular}{|l|}
0,002 \\
76742 \\
9 \\
\end{tabular} & $\begin{array}{l}0,001064 \\
396 \\
\end{array}$ & 0,018643755 & $\begin{array}{l}1,98443 \\
\text { E-05 } \\
\end{array}$ \\
\hline $\begin{array}{l}\text { Psychotria } \\
\text { nervosa }\end{array}$ & 6 & 0,4615 & 26 & \begin{tabular}{|l|}
0,002 \\
76742 \\
9 \\
\end{tabular} & $\begin{array}{l}0,001277 \\
275\end{array}$ & 0,01275625 & $\begin{array}{l}1,62932 \\
\text { E-05 }\end{array}$ \\
\hline Myrcia fallax & 5 & 0,3846 & 28 & \begin{tabular}{|l|}
0,002 \\
98030 \\
9 \\
\end{tabular} & $\begin{array}{l}0,001146 \\
273\end{array}$ & 0,0137375 & $\begin{array}{l}1,57469 \\
\text { E-05 }\end{array}$ \\
\hline $\begin{array}{l}\text { Calophyllum } \\
\text { calaba }\end{array}$ & 3 & 0,2308 & 8 & \begin{tabular}{|l|}
0,000 \\
85151 \\
7
\end{tabular} & $\begin{array}{l}0,000196 \\
504\end{array}$ & 0,07310313 & $\begin{array}{l}1 \\
4365 \mathrm{E}- \\
05\end{array}$ \\
\hline $\begin{array}{l}\text { Ficus } \\
\text { nymphaeifolia }\end{array}$ & 1 & 0,0769 & 1 & $\begin{array}{l}0,000 \\
10644\end{array}$ & $\begin{array}{l}8 \\
18766 \mathrm{E}- \\
06\end{array}$ & 1,5386 & $\begin{array}{l}1,25975 \\
\text { E-05 }\end{array}$ \\
\hline Cherimolia & 3 & 0,2308 & 25 & 0,002 & 0,000614 & 0,019625 & 1,20512 \\
\hline
\end{tabular}




\begin{tabular}{|c|c|c|c|c|c|c|c|}
\hline ternatensis & & & & 66099 & 075 & & E-05 \\
\hline $\begin{array}{l}\text { Croton } \\
\text { bixoides }\end{array}$ & 2 & 0,1538 & 22 & \begin{tabular}{|l|}
0,002 \\
34167 \\
1
\end{tabular} & $\begin{array}{l}0,000360 \\
257\end{array}$ & 0,02992813 & $\begin{array}{l}1,07818 \\
\text { E-05 }\end{array}$ \\
\hline $\begin{array}{l}\text { Coffea } \\
\text { liberica }\end{array}$ & 1 & 0,0769 & 43 & \begin{tabular}{|l|}
0,004 \\
57690 \\
3 \\
\end{tabular} & \begin{tabular}{|l}
0,000352 \\
069 \\
\end{tabular} & 0,02845625 & $\begin{array}{l}1,00186 \\
\text { E-05 }\end{array}$ \\
\hline $\begin{array}{l}\text { Annona } \\
\text { muricata }\end{array}$ & 3 & 0,2308 & 10 & \begin{tabular}{|l|}
0,001 \\
06439 \\
6 \\
\end{tabular} & $\begin{array}{l}0,000245 \\
63\end{array}$ & 0,04072188 & $\begin{array}{l}1,00025 \\
\text { E-05 }\end{array}$ \\
\hline $\begin{array}{l}\text { Swietenia } \\
\text { aubrevilleana }\end{array}$ & 5 & 0,3846 & 19 & \begin{tabular}{|l|}
0,002 \\
02235 \\
2
\end{tabular} & $\begin{array}{l}0,000777 \\
828\end{array}$ & 0,012265625 & $\begin{array}{l}9,54054 \\
\text { E-06 }\end{array}$ \\
\hline $\begin{array}{l}\text { Eugenia } \\
\text { pseudopsidiu } \\
m\end{array}$ & 2 & 0,1538 & 24 & $\begin{array}{l}0,002 \\
55455\end{array}$ & $\begin{array}{l}0,000393 \\
008\end{array}$ & 0,02060625 & $\begin{array}{l}8,09842 \\
\text { E-06 }\end{array}$ \\
\hline $\begin{array}{l}\text { Capparis } \\
\text { flexuosa }\end{array}$ & 6 & 0,4615 & 15 & \begin{tabular}{|l|}
0,001 \\
59659 \\
4 \\
\end{tabular} & $\begin{array}{l}0,000736 \\
89\end{array}$ & 0,010303125 & $\begin{array}{l}\text { 7,59226 } \\
\text { E-06 }\end{array}$ \\
\hline Clidemia hirta & 5 & 0,3846 & 16 & \begin{tabular}{|l|}
0,001 \\
70303 \\
4 \\
\end{tabular} & $\begin{array}{l}0,000655 \\
013\end{array}$ & 0,00785 & \begin{tabular}{|l}
5,14185 \\
E-06
\end{tabular} \\
\hline $\begin{array}{l}\text { Lonchocarpus } \\
\text { heptaphyllus }\end{array}$ & 2 & 0,1538 & 2 & $\begin{array}{l}0,000 \\
21287 \\
9\end{array}$ & $\begin{array}{l}3,27506 \\
\text { E-05 }\end{array}$ & 0,1197125 & $\begin{array}{l}3,92066 \\
\text { E-06 }\end{array}$ \\
\hline Cola nitida & 1 & 0,0769 & 7 & \begin{tabular}{|l|}
0,000 \\
74507 \\
7 \\
\end{tabular} & \begin{tabular}{|l}
5,73136 \\
E-05
\end{tabular} & 0,05642188 & \begin{tabular}{|l}
3,23374 \\
E-06
\end{tabular} \\
\hline $\begin{array}{l}\text { Pisonia } \\
\text { suborbiculata }\end{array}$ & 1 & 0,0769 & 11 & $\begin{array}{l}0,001 \\
17083 \\
6\end{array}$ & $\begin{array}{l}9,00643 \\
\text { E-05 }\end{array}$ & 0,03434375 & $\begin{array}{l}3,09314 \\
\text { E-06 }\end{array}$ \\
\hline Ocotea patens & 2 & 0,1538 & 5 & \begin{tabular}{|l|}
0,000 \\
53219 \\
8 \\
\end{tabular} & \begin{tabular}{|l}
8, \\
$18766 \mathrm{E}-$ \\
05
\end{tabular} & 0,033362505 & $\begin{array}{l}2,73161 \\
\text { E-06 }\end{array}$ \\
\hline $\begin{array}{l}\text { Cestrum } \\
\text { laurifolium }\end{array}$ & 2 & 0,1538 & 13 & \begin{tabular}{|l|}
0,001 \\
38371 \\
5 \\
\end{tabular} & $\begin{array}{l}0,000212 \\
879 \\
\end{array}$ & 0,00932188 & \begin{tabular}{|l|}
1, \\
$98443 \mathrm{E}-$ \\
06 \\
\end{tabular} \\
\hline $\begin{array}{l}\text { Bambusa } \\
\text { vulgaris }\end{array}$ & 2 & 0,1538 & 14 & $\begin{array}{l}0,001 \\
49015 \\
4\end{array}$ & $\begin{array}{l}0,000229 \\
255\end{array}$ & 0,00686875 & $\begin{array}{l}1,57469 \\
\text { E-06 }\end{array}$ \\
\hline $\begin{array}{l}\text { Cestrum } \\
\text { megalophyllu } \\
m\end{array}$ & 1 & 0,0769 & 12 & \begin{tabular}{|l|}
0,001 \\
27727 \\
5
\end{tabular} & $\begin{array}{l}9,82519 \\
\text { E-05 }\end{array}$ & 0,01471875 & $\begin{array}{l}1, \\
44615 \mathrm{E}- \\
06\end{array}$ \\
\hline $\begin{array}{l}\text { Cocos } \\
\text { nucifera }\end{array}$ & 1 & 0,0769 & 5 & $\begin{array}{l}0,000 \\
53219 \\
8\end{array}$ & $\begin{array}{l}4,09383 \\
\text { E-05 }\end{array}$ & 0.0314 & $\begin{array}{l}1,28546 \\
\text { E-06 }\end{array}$ \\
\hline $\begin{array}{l}\text { Margaritaria } \\
\text { nobilis }\end{array}$ & 1 & 0,0769 & 1 & \begin{tabular}{|l|}
0,000 \\
10644
\end{tabular} & \begin{tabular}{|l|}
8,18766 \\
E-06
\end{tabular} & 0.1256 & \begin{tabular}{|l|}
1,02837 \\
E-06
\end{tabular} \\
\hline Acasia retusa & 5 & 0,3846 & 7 & \begin{tabular}{|l|}
0,000 \\
74507 \\
7
\end{tabular} & $\begin{array}{l}0,000286 \\
568\end{array}$ & 0,003434375 & $\begin{array}{l}9,84182 \\
\text { E-07 }\end{array}$ \\
\hline $\begin{array}{l}\text { Piper } \\
\text { aduncum }\end{array}$ & 2 & 0,1538 & 5 & $\begin{array}{l}0,000 \\
53219 \\
8\end{array}$ & $\begin{array}{l}8,18766 \\
\text { E-05 }\end{array}$ & 0,01128438 & $\begin{array}{l}9,23927 \\
\text { E-07 }\end{array}$ \\
\hline Macfadyena & 5 & 0,3846 & 4 & 0,000 & 0,000163 & 0,00490625 & 8,03414 \\
\hline
\end{tabular}




\begin{tabular}{|c|c|c|c|c|c|c|c|}
\hline unguis-cati & & & & \begin{tabular}{|l}
42575 \\
8
\end{tabular} & 753 & & E-07 \\
\hline $\begin{array}{l}\text { Eugenia } \\
\text { cordata }\end{array}$ & 2 & 0,1538 & 6 & \begin{tabular}{|l|}
0,000 \\
63863 \\
8 \\
\end{tabular} & \begin{tabular}{|l|}
9 \\
$82519 \mathrm{E}-$ \\
05
\end{tabular} & 0,004415625 & \begin{tabular}{|l|}
4, \\
$33844 \mathrm{E}-$ \\
07
\end{tabular} \\
\hline $\begin{array}{l}\text { Gonzalacunia } \\
\text { spicata }\end{array}$ & 3 & 0,2308 & 6 & \begin{tabular}{|l|}
0,000 \\
63863 \\
8
\end{tabular} & $\begin{array}{l}0,000147 \\
378\end{array}$ & 0,00294375 & \begin{tabular}{|l}
4, \\
$33844 \mathrm{E}-$ \\
07
\end{tabular} \\
\hline $\begin{array}{l}\text { Pisonia } \\
\text { aculeata }\end{array}$ & 3 & 0,2308 & 6 & \begin{tabular}{|l|}
0,000 \\
63863 \\
8
\end{tabular} & $\begin{array}{l}0,000147 \\
378\end{array}$ & 0,00294375 & $\begin{array}{l}4,33844 \\
\text { E-07 }\end{array}$ \\
\hline $\begin{array}{l}\text { Justicia } \\
\text { secunda }\end{array}$ & 2 & 0,1538 & 7 & \begin{tabular}{|l|}
0,000 \\
74507 \\
7
\end{tabular} & $\begin{array}{l}0,000114 \\
627\end{array}$ & 0,003434375 & $\begin{array}{l}3,93673 \\
\text { E-07 }\end{array}$ \\
\hline $\begin{array}{l}\text { Miconia } \\
\text { laevigata }\end{array}$ & 2 & 0,1538 & 7 & \begin{tabular}{|l|}
0,000 \\
74507 \\
7 \\
\end{tabular} & $\begin{array}{l}0,000114 \\
627\end{array}$ & 0,003434375 & $\begin{array}{l}3,93673 \\
\text { E-07 }\end{array}$ \\
\hline $\begin{array}{l}\text { Eugenia } \\
\text { tapacumensis }\end{array}$ & 1 & 0,0769 & 9 & $\begin{array}{l}0,000 \\
95795 \\
6\end{array}$ & $\begin{array}{l}\text { 7,3689T } \\
\text { H-05 }\end{array}$ & 0,004415625 & $\begin{array}{l}3,25383 \\
\text { E-07 }\end{array}$ \\
\hline $\begin{array}{l}\text { Casearia } \\
\text { decandra }\end{array}$ & 2 & 0,1538 & 2 & $\begin{array}{l}0,000 \\
21287 \\
9\end{array}$ & $\begin{array}{l}3,27506 \\
\text { E-05 }\end{array}$ & 0,008340625 & $\begin{array}{l}2,73161 \\
\text { E-07 }\end{array}$ \\
\hline $\begin{array}{l}\text { Eugenia } \\
\text { ligustrina }\end{array}$ & 4 & 0,3077 & 4 & \begin{tabular}{|l|}
0,000 \\
42575 \\
8 \\
\end{tabular} & $\begin{array}{l}0,000131 \\
003\end{array}$ & 0,0019625 & $\begin{array}{l}2,57093 \\
\text { E-07 }\end{array}$ \\
\hline $\begin{array}{l}\text { Ocotea } \\
\text { cernua? }\end{array}$ & 1 & 0,0769 & 1 & $\begin{array}{l}0,000 \\
10644\end{array}$ & $\begin{array}{l}8,18766 \\
\text { E-06 }\end{array}$ & 0.0314 & \begin{tabular}{|l|}
2,57093 \\
E-07
\end{tabular} \\
\hline $\begin{array}{l}\text { Pouteria } \\
\text { multiflora }\end{array}$ & 4 & 0,3077 & 1 & \begin{tabular}{|l|}
0,000 \\
10644 \\
\end{tabular} & \begin{tabular}{|l|}
3,27506 \\
E-05 \\
\end{tabular} & 0,00785 & \begin{tabular}{|l|}
2,57093 \\
E-07 \\
\end{tabular} \\
\hline Costus afer & 2 & 0,1538 & 5 & $\begin{array}{l}0,000 \\
53219 \\
8\end{array}$ & \begin{tabular}{|l}
8,18766 \\
E-05
\end{tabular} & 0,002453125 & $\begin{array}{l}2,00854 \\
\text { E-07 }\end{array}$ \\
\hline $\begin{array}{l}\text { Cissus } \\
\text { sicyoides }\end{array}$ & 1 & 0,0769 & 2 & $\begin{array}{l}0,000 \\
21287 \\
9\end{array}$ & $\begin{array}{l}1,63753 \\
\text { E-05 }\end{array}$ & 0,0098125 & $\begin{array}{l}1,60683 \\
\text { E-07 }\end{array}$ \\
\hline $\begin{array}{l}\text { Spathodea } \\
\text { campanulata }\end{array}$ & 1 & 0,0769 & 1 & \begin{tabular}{|l|}
0,000 \\
10644
\end{tabular} & \begin{tabular}{|l|}
8,18766 \\
E-06
\end{tabular} & 0,0176625 & $\begin{array}{l}1,44615 \\
\text { E-07 }\end{array}$ \\
\hline Aiphanes sp & 2 & 0,1538 & 1 & \begin{tabular}{|l|}
0,000 \\
10644 \\
\end{tabular} & \begin{tabular}{|l|}
1,63753 \\
E-05
\end{tabular} & 0,00785 & \begin{tabular}{|l|}
1,28546 \\
E-07
\end{tabular} \\
\hline $\begin{array}{l}\text { Passiflora } \\
\text { suberosa }\end{array}$ & 2 & 0,1538 & 4 & $\begin{array}{l}0,000 \\
42575 \\
8\end{array}$ & $\begin{array}{l}6,55013 \\
\text { E-05 }\end{array}$ & 0,0019625 & $\begin{array}{l}1,28546 \\
\text { E-07 }\end{array}$ \\
\hline $\begin{array}{l}\text { Myrciaria } \\
\text { floribunda }\end{array}$ & 2 & 0,1538 & 3 & $\begin{array}{l}0,000 \\
31931 \\
9\end{array}$ & $\begin{array}{l}4,9126 \mathrm{E}- \\
05\end{array}$ & 0,001471875 & \begin{tabular}{|l}
7,23073 \\
E-08
\end{tabular} \\
\hline $\begin{array}{l}\text { Cestrum } \\
\text { martinicensis }\end{array}$ & 1 & 0,0769 & 4 & \begin{tabular}{|l|}
0,000 \\
42575 \\
8 \\
\end{tabular} & $\begin{array}{l}3,27506 \\
\text { E-05 }\end{array}$ & 0,0019625 & \begin{tabular}{|l}
6,42731 \\
E-08
\end{tabular} \\
\hline $\begin{array}{l}\text { Paullinia } \\
\text { cururu }\end{array}$ & 3 & 0,2308 & 2 & \begin{tabular}{|l|}
0,000 \\
21287 \\
9
\end{tabular} & $\begin{array}{l}4,9126 \mathrm{E}- \\
05\end{array}$ & 0,00098125 & $\begin{array}{l}4,82049 \\
\text { E-08 }\end{array}$ \\
\hline $\begin{array}{l}\text { Securidaca } \\
\text { diversifolia }\end{array}$ & 3 & 0,2308 & 2 & $\begin{array}{l}0,000 \\
21287 \\
9\end{array}$ & $\begin{array}{l}4,9126 \mathrm{E}- \\
05\end{array}$ & 0,00098125 & $\begin{array}{l}4,82049 \\
\text { E-08 }\end{array}$ \\
\hline
\end{tabular}




\begin{tabular}{|c|c|c|c|c|c|c|c|}
\hline $\begin{array}{l}\text { Maytenus } \\
\text { laevigata }\end{array}$ & 1 & 0,0769 & 2 & \begin{tabular}{|l|}
0,000 \\
21287 \\
9
\end{tabular} & $\begin{array}{l}1,63753 \\
\text { E-05 }\end{array}$ & 0,00245313 & $\begin{array}{l}4,01708 \\
\text { E-08 }\end{array}$ \\
\hline $\begin{array}{l}\text { Bambusa } \\
\text { multiplex }\end{array}$ & 8 & 0,6154 & 1 & $\begin{array}{l}0,000 \\
10644\end{array}$ & \begin{tabular}{|l|}
6,55013 \\
E-05
\end{tabular} & 0,000490625 & $\begin{array}{l}3,21366 \\
\text { E-08 }\end{array}$ \\
\hline $\begin{array}{l}\text { Passiflora } \\
\text { laurifolia }\end{array}$ & 2 & 0,1538 & 2 & \begin{tabular}{|l|}
0,000 \\
21287 \\
9 \\
\end{tabular} & $\begin{array}{l}3,27506 \\
\text { E-05 }\end{array}$ & 0,00098125 & $\begin{array}{l}3,21366 \\
\text { E-08 } \\
\end{array}$ \\
\hline $\begin{array}{l}\text { Swietenia } \\
\text { macrophylla }\end{array}$ & 2 & 0,1538 & 2 & \begin{tabular}{|l|}
0,000 \\
21287 \\
9 \\
\end{tabular} & $\begin{array}{l}3,27506 \\
\text { E-05 } \\
\end{array}$ & 0,00098125 & $\begin{array}{l}3,21366 \\
\text { E-08 } \\
\end{array}$ \\
\hline $\begin{array}{l}\text { Genipa } \\
\text { americana }\end{array}$ & 1 & 0,0769 & 2 & \begin{tabular}{|l|}
0,000 \\
21287 \\
9
\end{tabular} & $\begin{array}{l}1,63753 \\
\text { E-05 }\end{array}$ & 0,00098125 & $\begin{array}{l}1,60683 \\
\text { E-08 }\end{array}$ \\
\hline MALVACEAE & 1 & 0,0769 & 2 & \begin{tabular}{|l|}
0,000 \\
21287 \\
9
\end{tabular} & $\begin{array}{l}1,63753 \\
\text { E-05 }\end{array}$ & 0,00098125 & $\begin{array}{l}1,60683 \\
\text { E-08 }\end{array}$ \\
\hline $\begin{array}{l}\text { Theobroma } \\
\text { cacao }\end{array}$ & 1 & 0,0769 & 2 & \begin{tabular}{|l|}
0,000 \\
21287 \\
9 \\
\end{tabular} & $\begin{array}{l}1,63753 \\
\text { E-05 } \\
\end{array}$ & 0,00098125 & $\begin{array}{l}1,60683 \\
\text { E-08 } \\
\end{array}$ \\
\hline Acacia $s p$ & 2 & 0,1538 & 1 & \begin{tabular}{|l|}
0,000 \\
10644
\end{tabular} & \begin{tabular}{|l}
1,63753 \\
E-05
\end{tabular} & 0,000490625 & $\begin{array}{l}8,03414 \\
\text { E-09 }\end{array}$ \\
\hline $\begin{array}{l}\text { Gouania } \\
\text { lupuloides }\end{array}$ & 2 & 0,1538 & 1 & $\begin{array}{l}0,000 \\
10644\end{array}$ & $\begin{array}{l}1,63753 \\
\text { E-05 }\end{array}$ & 0,000490625 & $\begin{array}{l}8,03414 \\
\text { E-09 }\end{array}$ \\
\hline $\begin{array}{l}\text { Heterotis } \\
\text { rotundifolia }\end{array}$ & 2 & 0,1538 & 1 & \begin{tabular}{|l|}
0,000 \\
10644 \\
\end{tabular} & \begin{tabular}{|l|}
1,63753 \\
E-05 \\
\end{tabular} & 0,000490625 & \begin{tabular}{|l}
8,03414 \\
E-09 \\
\end{tabular} \\
\hline Paullinia $s p$ & 2 & 0,1538 & 1 & \begin{tabular}{|l|}
0,000 \\
10644
\end{tabular} & \begin{tabular}{|l|}
1,63753 \\
E-05
\end{tabular} & 0,000490625 & $\begin{array}{l}8,03414 \\
\text { E-09 }\end{array}$ \\
\hline $\begin{array}{l}\text { Aegiphila } \\
\text { martinicensis }\end{array}$ & 1 & 0,0769 & 1 & $\begin{array}{l}0,000 \\
10644\end{array}$ & $\begin{array}{l}8,18766 \\
\text { E-06 }\end{array}$ & 0,000490625 & $\begin{array}{l}4,01707 \\
\text { E-09 }\end{array}$ \\
\hline $\begin{array}{l}\text { Eugenia } \\
\text { oerstedeana }\end{array}$ & 1 & 0,0769 & 1 & \begin{tabular}{|l|}
0,000 \\
10644 \\
\end{tabular} & \begin{tabular}{|l|}
8,18766 \\
E-06 \\
\end{tabular} & 0,000490625 & $\begin{array}{l}4,01707 \\
\text { E-09 } \\
\end{array}$ \\
\hline $\begin{array}{l}\text { Faramea } \\
\text { occidentalis }\end{array}$ & 1 & 0,0769 & 1 & \begin{tabular}{|l|}
0,000 \\
10644 \\
\end{tabular} & \begin{tabular}{|l|}
8,18766 \\
E-06 \\
\end{tabular} & 0,000490625 & $\begin{array}{l}4,01707 \\
\text { E-09 } \\
\end{array}$ \\
\hline $\begin{array}{l}\text { Solanum } \\
\text { torvum }\end{array}$ & 1 & 0,0769 & 1 & \begin{tabular}{|l|}
0,000 \\
10644
\end{tabular} & \begin{tabular}{|l}
8,18766 \\
E-06
\end{tabular} & 0,000490625 & $\begin{array}{l}4,01707 \\
\text { E-09 }\end{array}$ \\
\hline $\begin{array}{l}\text { Spondias } \\
\text { mombin }\end{array}$ & 1 & 0,0769 & 1 & $\begin{array}{l}0,000 \\
10644\end{array}$ & $\begin{array}{l}8,18766 \\
\text { E-06 }\end{array}$ & 0,000490625 & $\begin{array}{l}4,01707 \\
\text { E-09 }\end{array}$ \\
\hline $\begin{array}{l}\text { Zanthoxylum } \\
\text { monophyllum }\end{array}$ & 1 & 0,0769 & 1 & \begin{tabular}{|l|}
0,000 \\
10644 \\
\end{tabular} & \begin{tabular}{|l|}
8,18766 \\
E-06 \\
\end{tabular} & 0,00049025 & $\begin{array}{l}4,014 \mathrm{E}- \\
09 \\
\end{array}$ \\
\hline $\begin{array}{l}\text { Abrus } \\
\text { precatorius }\end{array}$ & 1 & 0,0769 & & & & & \\
\hline $\begin{array}{l}\text { Aechmea } \\
\text { fasciata }\end{array}$ & 1 & 0,0769 & & & & & \\
\hline $\begin{array}{l}\text { Alocasia } \\
\text { macrorrhiza }\end{array}$ & 2 & 0,1538 & 2 & \begin{tabular}{|l|}
0,000 \\
21287 \\
9 \\
\end{tabular} & $\begin{array}{l}3,27506 \\
\text { E-05 } \\
\end{array}$ & & \\
\hline $\begin{array}{l}\text { Bromelia } \\
\text { karatas }\end{array}$ & 2 & 0,1538 & 4 & \begin{tabular}{|l|}
0,000 \\
42575 \\
8 \\
\end{tabular} & $\begin{array}{l}6,55013 \\
\text { E-05 } \\
\end{array}$ & & \\
\hline $\begin{array}{l}\text { Chimarrhis } \\
\text { cymosa }\end{array}$ & 1 & 0,0769 & & & & & \\
\hline Alocasia SP. & 1 & 0,0769 & 2 & $\begin{array}{l}0,000 \\
21287 \\
9 \\
\end{array}$ & \begin{tabular}{|l|}
1 \\
$63753 \mathrm{E}-$ \\
05
\end{tabular} & & \\
\hline
\end{tabular}




\begin{tabular}{|c|c|c|c|c|c|c|c|}
\hline Costus sp & 1 & 0,0769 & & & & & \\
\hline $\begin{array}{l}\text { Eugenia } \\
\text { gregii }\end{array}$ & 1 & 0,0769 & & & & & \\
\hline $\begin{array}{l}\text { Heliconia } \\
\text { caribaea }\end{array}$ & 1 & 0,0769 & & & & & \\
\hline $\begin{array}{l}\text { Heteropterys } \\
\text { platyptera }\end{array}$ & 1 & 0,0769 & & & & & \\
\hline $\begin{array}{l}\text { Hippocratea } \\
\text { volubilis }\end{array}$ & 1 & 0,0769 & & & & & \\
\hline $\begin{array}{l}\text { Hymenocallis } \\
\text { caribaea }\end{array}$ & 1 & 0,0769 & & & & & \\
\hline Iротоеа $s p$ & 3 & 0,2308 & & & & & \\
\hline $\begin{array}{l}\text { Kalanchoe } \\
\text { pinnata }\end{array}$ & 1 & 0,0769 & & & & & \\
\hline $\begin{array}{l}\text { Liane } \\
\text { Fabaceae }\end{array}$ & 1 & 0,0769 & & & & & \\
\hline $\begin{array}{l}\text { Melicoccus } \\
\text { bijugatus }\end{array}$ & 1 & 0,0769 & & & & & \\
\hline $\begin{array}{l}\text { Nephrolepis } \\
\text { rivularis }\end{array}$ & 2 & 0,1538 & & & & & \\
\hline $\begin{array}{l}\text { Ocotea } \\
\text { leucoxylon }\end{array}$ & 1 & 0,0769 & & & & & \\
\hline $\begin{array}{l}\text { Palicourea } \\
\text { crosea }\end{array}$ & 1 & 0,0769 & & & & & \\
\hline $\begin{array}{l}\text { Passiflora } \\
\text { edulis }\end{array}$ & 2 & 0,1538 & & & & & \\
\hline $\begin{array}{l}\text { Peperomia } \\
\text { rotundifolia }\end{array}$ & 2 & 0,1538 & & & & & \\
\hline $\begin{array}{l}\text { Prunus } \\
\text { angustifolia }\end{array}$ & 1 & 0,0769 & & & & & \\
\hline $\begin{array}{l}\text { Polypodium } \\
\text { SP. }\end{array}$ & 2 & 0,1538 & & & & & \\
\hline $\begin{array}{l}\text { Polypodium } \\
\text { SP. (epiphyte) }\end{array}$ & 1 & 0,0769 & & & & & \\
\hline $\begin{array}{l}\text { Psychotria } \\
\text { tenuifolia }\end{array}$ & 1 & 0,0769 & & & & & \\
\hline $\begin{array}{l}\text { Quararibea } \\
\text { turbinata }\end{array}$ & 1 & 0,0769 & & & & & \\
\hline Smilax sp & 1 & 0,0769 & & & & & \\
\hline Sad Solanum & 1 & 0,0769 & 1 & $\begin{array}{l}0,000 \\
10644\end{array}$ & \begin{tabular}{|l|}
8,18766 \\
E-06
\end{tabular} & & \\
\hline $\begin{array}{l}\text { Syngonium } \\
\text { podophyllum }\end{array}$ & 6 & 0,4615 & & & & & \\
\hline $\begin{array}{l}\text { Thelypteris } \\
\text { reticulata }\end{array}$ & 1 & 0,0769 & & & & & \\
\hline Tillandsia $s p$ & 1 & 0,0769 & & & & & \\
\hline $\begin{array}{l}\text { Urvillea } \\
\text { ulmacea }\end{array}$ & 2 & 0,1538 & & & & & \\
\hline $\begin{array}{l}\text { Weof the } \\
\text { calycina }\end{array}$ & 1 & 0,0769 & & & & & \\
\hline
\end{tabular}




\section{Annex 2:-}

Abrus precatorius (Ap)/ Acasia retusa (Ar)/ Acasia sp (Asp)/Aechmea fasciata (Af)/ Aegiphila martinicensis (Am)/ Aiphanes sp (Aisp)/Alocasia sp (As)/Amphilophium paniculatum (Ap)/Andira inermis (Ai)/Annona muricata (Am)/Artocarpus altilis (Aa)/Bambusa multiplex (Bm)/Bambusa vulgaris (Bv)/Bourreria succulenta (Bs)/Bromelia karatas (Bk)/Brosimum alicastrum (Ba)/Bursera simaruba (Bs)/Calliandra tergemina (Ct)/ Calophyllum calaba (Cc)/Capparis baducca(Cb)/Capparis flexuosa (Cf)/Capparis indica (Ci)/Casearia decandra (Cd)/Cassia sp $(\mathrm{Cs}) /$ Cecropia schreberiana (Ce)/ Ceiba pentandra (Cp)/ Cestrum laurifolium (Cl)/ Cestrum martinicensis (Cma)/Cestrum megalophyllum (Cmeg)/Chimarrhis cymosa (Ccy)/Chiococca alba (Cal)/ Chionanthus compacta (Chc)/ Chou Blanc (Cb)/Chrysophyllum argenteum (Chra)/Cissus sicyoides (Csc)/ Citharexylum spinosum (Cspi)/ Clidemia hirta (Clhi)/ Coccoloba swartzii (Csw)/ Cocos nucifera (Cnu)/ Coffea liberica (Clib)/ Cola nitida (Cni)/ Conostegia montana (Com)/ Cordia alliodora (Cora)/Cordia sulcata (Corsu)/ Cornutia pyramidata (Cpy)/ Croton bixoides (Cbi)/Croton corylifolius (Ccory)/ Costus afer (Caf)/ Costus sp (Cosp)/ Cupania americana (Cuam)/ Daphnopsis americana (Dapa)/ Dieffenbachia seguine (Dies)/Erythroxylon havanense (Erh)/ Eugenia cordata (Euc)/ Eugenia gregii (Eug)/ Eugenia ligustrina (Eul)/ Eugenia monticola (Eum)/ Eugenia oerstedeana (Euoe)/ Eugenia pseudopsidium (Eups)/ Eugenia tapacumensis (Eut)/ Faramea occidentalis (Fao)/ Ficus nymphaeifolia (Fny)/ Funtumia elastica (Fel)/ Genipa americana (Gam)/ Gonzalacunia spicata (Gsp)/ Gouania lupuloides (Glu)/ Guettarda odorata (God)/

Guettarda scabra (Gsc)/ Haematoxylon campechianum (Hca)/ Heliconia caribaea (Hca)/ Heteropterys platyptera (Hpu)/ Heterotis rotundifolia (Hro)/ Hippocratea volubilis (Hvo)/ Hirtella triandra (Htr)/ Homalium racemosum (Hra)/ Hymenaea courbaril (Hco)/ Hymenocallis caribaea (Hca)/ Inga ingoides (Iin)/ Inga laurina (Ila)/I Ipomoea sp (Isp)/Justicia secunda (Jse)/Kalanchoe pinnata (Kpi)/Liane Fabaceae Lfa)/Licania ternatensis (Lte)/ Lonchocarpus heptaphyllus (Lhe)/ Lonchocarpus punctatus (Lpu)/ Macfadyena unguis cati (Mun)/ Malvaceae (Mal)/ Mammea americana (Mam)/ Mangifera indica (Min)/Margaritaria nobilis $\quad$ (Mno)/ Maytenus laevigata (Mla)/ Melicoccus bijugatus (Mbi)/Miconia laevigata (Mla)/ Myrcia citrifolia (Mci)/ Myrcia fallax (Mfa)/Myrcia splendens (Msp)/ Myrciaria floribunda (Mflo)/ Nephrolepis rivularis (Nri)/ Ocotea cernua (Ocer)/ Ocotea eggersiana? (Oeg)/ Ocotea coriacea (Oco)/Ocotea leucoxylon (Ole)/Ocotea patens $\quad$ (Opa)/

Odontonemanitidum (Oni)/ Palicourea crosea (Pcr)/ Passiflora edulis (Ped)/ Passiflora laurifolia (Pla)/ Passiflora suberosa (Psu)/ Paullinia cururu (Pcu)/ Paullinia sp (Psp)/ Peperomia rotundifolia (Pro)/ Petrea kohautiana (Pko)/ Pimenta racemosa (Pra)/ Piper aduncum (Pad)/ Piper amalago (Pam)/ Piper dilatatum (Pdi)/ Piper reticulatum (Pre)/ Pisonia aculeata (Pac)/ Pisonia fragrans (Pfr)/ Pisonia suborbiculata (Psu)/ Pitcairnia angustifolia (Pan)/ Polypodium sp (Posp1)/ Polypodium sp (épiphyte) (Posp2)/ Pouteria multiflora (Pmu)/ Psychotria mapourioides (Pma)/ Psychotria microdon (Pmi)/ Psychotria nervosa (Pne)/Psychotria tenuifolia (Pte)/ Quararibea turbinata (Qtu)/ Randia aculeata (Rac)/

Samanea saman (Ssa)/Sapium caribaeum (Sca)/ Securidaca diversifolia (Sdi)/ Simarouba amara (Sam)/ Smilax sp (Sgu)/Solanum torvum (Sto)/Solanum triste (Str)/Spathodea campanulata (Sca)/Spondias mombin $\quad$ (Smo)/ Swietenia aubrevilleana (Sau)/ Swietenia macrophylla (Sma)/ Swietenia mahagoni (Smah)/ Syngonium podophyllum (Spo)/ Tabebuia heterophylla (The)/ Tabernaemontana citrifolia (Tci)/ Terminalia catappa (Tca)/ Thelypteris reticulata (Tre)/ Theobroma cacao (Thca)/ Tillandsia sp (Tsp)/ Urvillea ulmacea (Uum)/Vitex divaricata (Vdi)/ Wedelia calycina (Wca)/ Zanthoxylum caribaeum (Zca)/ Zanthoxylum monophyllum (Zmo). 